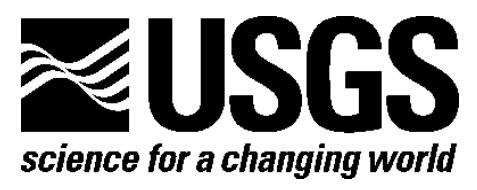

\title{
Sediment Deposition, Erosion, and Bathymetric Change in Central San Francisco Bay: 1855-1979
}

\author{
By Theresa A. Fregoso, Amy C. Foxgrover, and Bruce E. Jaffe
}

\section{Open-File Report 2008-1312}

U.S. Department of the Interior

U.S. Geological Survey 


\section{U.S. Department of the Interior \\ DIRK KEMPTHORNE, Secretary}

\section{U.S. Geological Survey \\ Mark D. Myers, Director}

U.S. Geological Survey, Reston, Virginia 2008

For product and ordering information:

World Wide Web: http://www.usgs.gov/pubprod

Telephone: 1-888-ASK-USGS

For more information on the USGS-the Federal source for science about the Earth,

its natural and living resources, natural hazards, and the environment:

World Wide Web: http://www.usgs.gov

Telephone: 1-888-ASK-USGS

Suggested citation:

Fregoso, T.A., Foxgrover, A.C., Jaffe, B.E., 2008, Sediment deposition, erosion, and bathymetric change in central San Francisco Bay: 1855-1979: U.S. Geological Survey Open-File Report 2008-1312., 41 p.

Any use of trade, product, or firm names is for descriptive purposes only and does not imply endorsement by the U.S. Government.

Although this report is in the public domain, permission must be secured from the individual copyright owners to reproduce any copyrighted material contained within this report. 


\section{Contents}

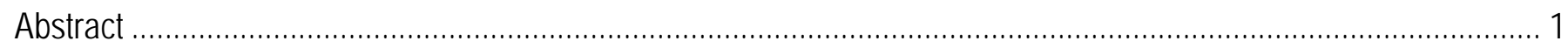

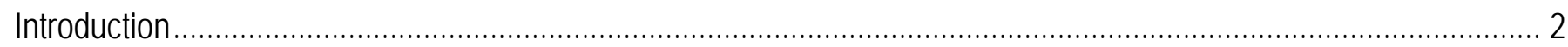

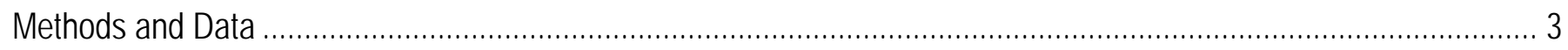

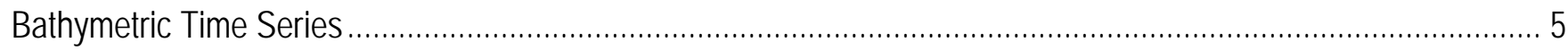

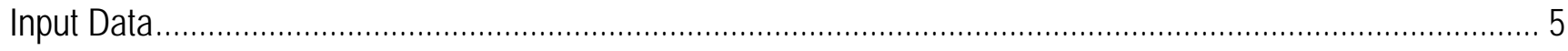

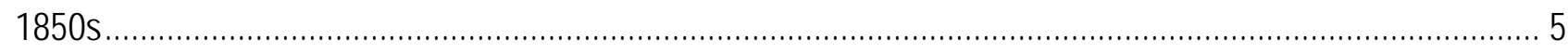

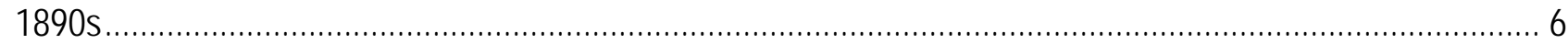

1920 s

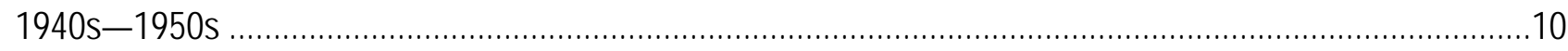

1980s

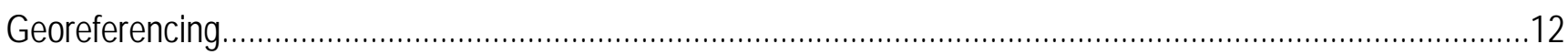

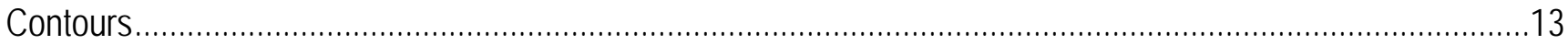

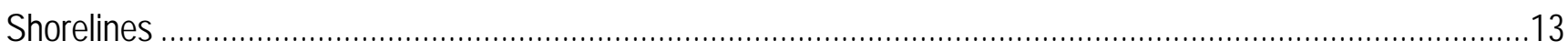

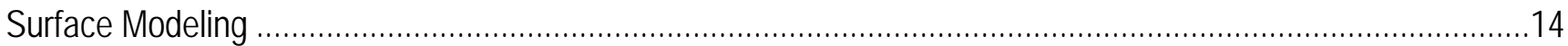

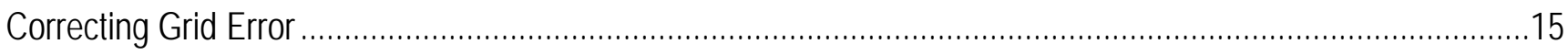

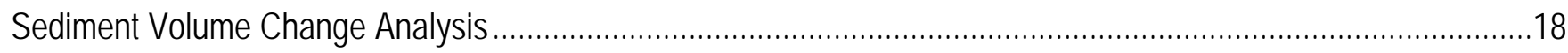

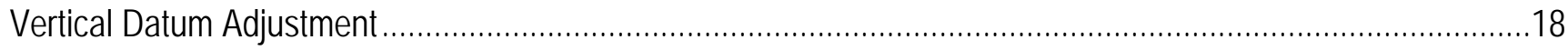

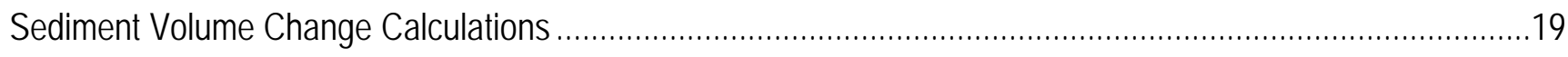

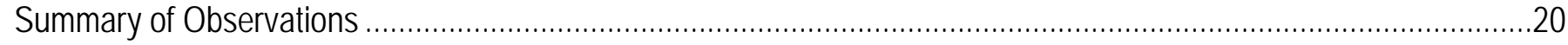

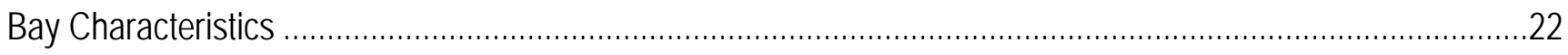

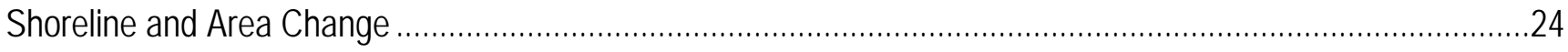

Area of Marsh 


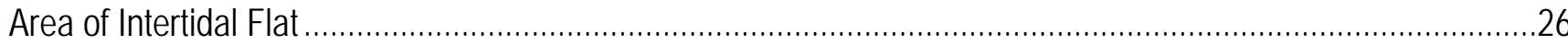

Sediment Volume Changes in Central San Francisco Bay ......................................................................27

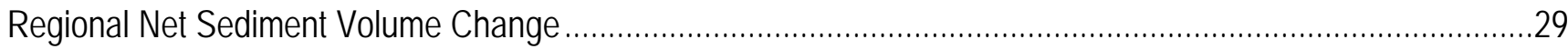

Anthropogenic Impacts on Net Sediment Volume Change........................................................................32

Future Work

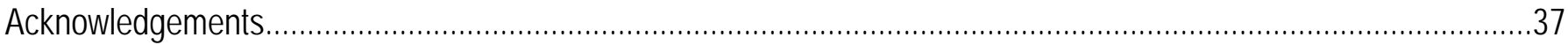

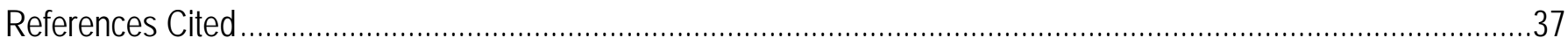

Appendix 1: Differences in Net Volumes by Region when Accounting for Sediment Removed from the System.........39

Appendix 2: Amounts of Dredged Material as Recorded by the U.S. Army Corp of Engineers (1975)........................40

\section{List of Figures}

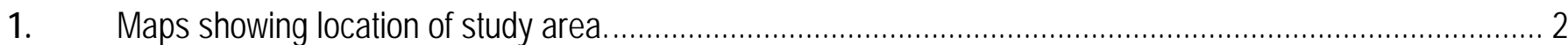

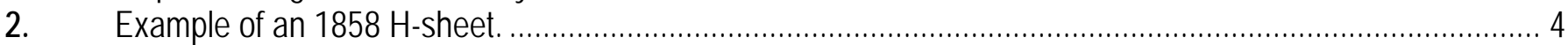

3. $\quad$ Maps showing 1850s soundings (left) and contours (right) used for surface modeling ................................... 5

4. $\quad$ Maps showing 1890s soundings (left) and contours (right) used for surface modeling ................................... 7

5. $\quad$ Maps showing 1920s soundings (left) and contours (right) used for surface modeling.................................... 8

6. Maps showing 1920s shoreline and marsh data augmented with information from earlier and later surveys.....

7. Maps showing 1940s and 1950s soundings (left) and contours (right) used for surface modeling.............

7. Maps showing 1940 s and 1950 s soundings (left) and contours (right) used for surface modeling..................11

8. $\quad$ Maps showing 1980s soundings (left) and contours (right) used for surface modeling..................................12

9. Map showing Mean High Water (MHW) values assigned to the 1855 shoreline............................................14

10. Map showing example of visual error checking technique applied to both soundings and contours................15

11. Method for determining incorrectly entered sounding values by locating soundings with large differences from the grid value and comparing them to adjacent soundings. ....................................................................

12. Preliminary bathymetry maps of Central San Francisco Bay from 1855 to $1979 \ldots \ldots \ldots \ldots \ldots \ldots \ldots \ldots \ldots \ldots \ldots \ldots \ldots \ldots . .21$

13. Preliminary series of cross section profiles showing the geomorphology of the bay floor in 1855 and 1979,

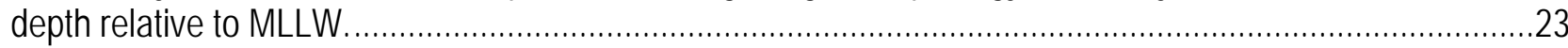

14. Map of shoreline change, including waterfront features, and graph showing area change in Central San

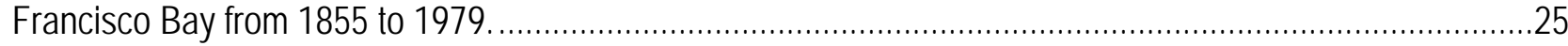

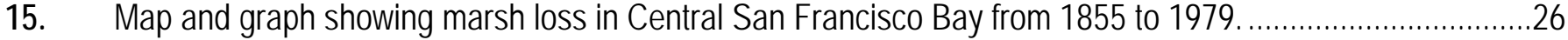

16. Map and graph showing change in intertidal flat area in Central San Francisco Bay from 1855 to 1979. ......27

17. Preliminary maps showing sediment deposition and erosion in Central San Francisco Bay over time from

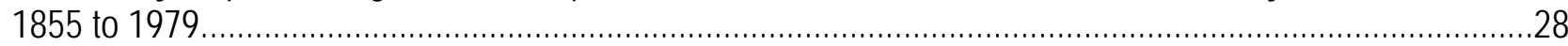

18. Map of Central San Francisco Bay showing the regions used for calculating regional net sediment volume

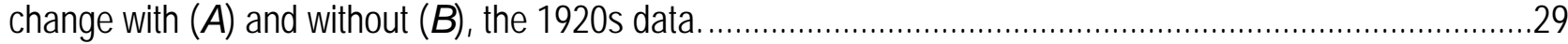

19. Graph Showing central San Francisco Bay preliminary net sediment volume change by region over time........

20. Graph showing preliminary regional rates of average bed level change over time (influences of borrow pits removed).. 
21. Maps showing some of the most discernable areas of man-made change over time, categorized by type.....34

22. Graph of Central San Francisco Bay preliminary net sediment volume change calculations over time. .........36

\section{Tables}

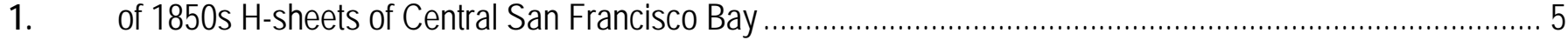

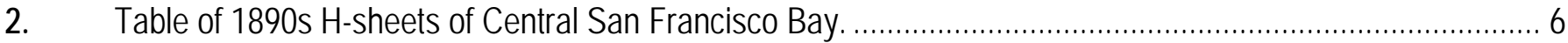

3. Table of 1920s H-sheets of Central San Francisco Bay. .................................................................... 7

4. Table of 1940s -1950s H-sheets of Central San Francisco Bay. ..........................................................10

5. Table of 1980s H-sheets of Central San Francisco Bay. ....................................................................12

6. Table of grid bias, representing difference between sounding values and corresponding grid cells. ............18

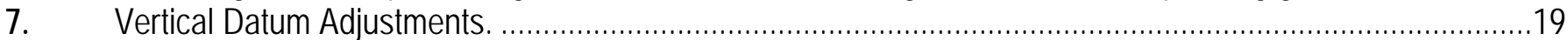

8. 1979 Central San Francisco Bay characteristics, depth value relative to MLLW......................................24 


\title{
Sediment Deposition, Erosion, and Bathymetric Change in Central San Francisco Bay: 1855-1979
}

\author{
By Theresa A. Fregoso, Amy C. Foxgrover, and Bruce E. Jaffe
}

\begin{abstract}
Central San Francisco Bay is the hub of a dynamic estuarine system connecting the San Joaquin and Sacramento River Deltas, Suisun Bay, and San Pablo Bay to the Pacific Ocean and South San Francisco Bay. To understand the role that Central San Francisco Bay plays in sediment transport throughout the system, it is necessary to first determine historical changes in patterns of sediment deposition and erosion from both natural and anthropogenic forces.

The first extensive hydrographic survey of Central San Francisco Bay was conducted in 1853 by the National Ocean Service (NOS) (formerly the United States Coast and Geodetic Survey (USCGS)). From 1894 to 1979, four additional surveys, composed of a total of approximately 700,000 bathymetric soundings, were collected within Central San Francisco Bay. Converting these soundings into accurate bathymetric models involved many steps. The soundings were either hand digitized directly from the original USCGS and NOS hydrographic sheets (H-sheets) or obtained digitally from the National Geophysical Data Center's (NGDC) Geophysical Data System (GEODAS) (National Geophysical Data Center, 1996). Soundings were supplemented with contours that were either taken directly from the Hsheets or added in by hand. Shorelines and marsh areas were obtained from topographic sheets. The digitized soundings, depth contours, shorelines, and marsh areas were entered into a geographic information system (GIS) and georeferenced to a common horizontal datum. Using surface modeling software, bathymetric grids with a horizontal resolution of $25 \mathrm{~m}$ were developed for each of the five hydrographic surveys. Before analyses of sediment deposition and erosion were conducted, interpolation bias was removed and all of the grids were converted to a common vertical datum. These bathymetric grids were then used to develop bathymetric change maps for subsequent survey periods and to determine long-term changes in deposition and erosion by calculating volumes and rates of net sediment change.

Central San Francisco Bay experienced periods of both deposition and erosion, but overall experienced a net gain in sediment from 1855 to 1979 of approximately $42 \times 10^{6} \mathrm{~m}^{3}\left(0.33 \times 10^{6} \mathrm{~m}^{3} / \mathrm{yr}\right)$. Over this same time period, 92 percent of the tidal marsh and 69 percent of the intertidal mudflats were lost as human activity increased and the shorefront was developed. During the first time period, from 1855 to 1895, Central San Francisco Bay was erosional, losing roughly $2 \times 10^{6} \mathrm{~m}^{3} / \mathrm{yr}$ of sediment. The next time period was depositional, with a net gain of approximately $3 \times 10^{6} \mathrm{~m}^{3} / \mathrm{yr}$ of sediment from 1895 to 1947 . The last time period, from 1947 to 1979 , was erosional again, losing roughly $2 \times 10^{6} \mathrm{~m}^{3}$ / yr of sediment. Sedimentation patterns also varied spatially. The northern part of Central San Francisco Bay was depositional during all change periods while the eastern region alternated between erosional and depositional.
\end{abstract}


Central San Francisco Bay sedimentation patterns have also been strongly impacted by anthropogenic activities, such as dredging and dredge disposal, borrow pits, and sand mining. For example, bathymetric change at a borrow pit created near Bay Farm Island sometime between the 1947 and 1979 surveys indicates roughly $25 \times 10^{6} \mathrm{~m}^{3}$ of sediment was removed from the system

\section{Introduction}

The San Francisco estuary is one of the largest in the United States with a watershed area of 177,699 km² (U.S. Environmental Protection Agency, 2008). Central San Francisco Bay is the hub of the estuarine system connecting the San Joaquin and Sacramento Rivers, Suisun Bay, and San Pablo Bay to the Pacific Ocean and South San Francisco Bay, and contains several islands including, Alcatraz Island, Angel Island, Treasure Island and Yerba Buena Island (fig. 1). As one of the few deep-water ports located along the west coast of the United States, San Francisco Bay became an important harbor for commerce and the military as the population of the region exploded after the beginning of the gold rush in 1849. At the time that the first hydrographic survey was collected in Central San Francisco Bay (1853), there were approximately 100,000 people living in the San Francisco Bay area; today it is home to nearly seven million (Bay Area Census, 2003). This rapid increase in population has placed a number of pressures upon the estuary. In addition to natural processes such as sea-level rise, climatic influences on sediment delivery, and wind wave erosion, human activities have altered patterns of sediment deposition and erosion throughout the estuary. Numerous dredging projects for shipping channels have had to keep pace with the increasing size of cargo ships and heightened activity within the bay. The usefulness of sand for construction, and as a fill material, resulted in sand mining operations starting in the late 1800s (Hanson Environmental Inc., 2004). Large amounts of sediment were removed or "borrowed" for use in shoreline and harbor development and in the creation of Treasure Island.
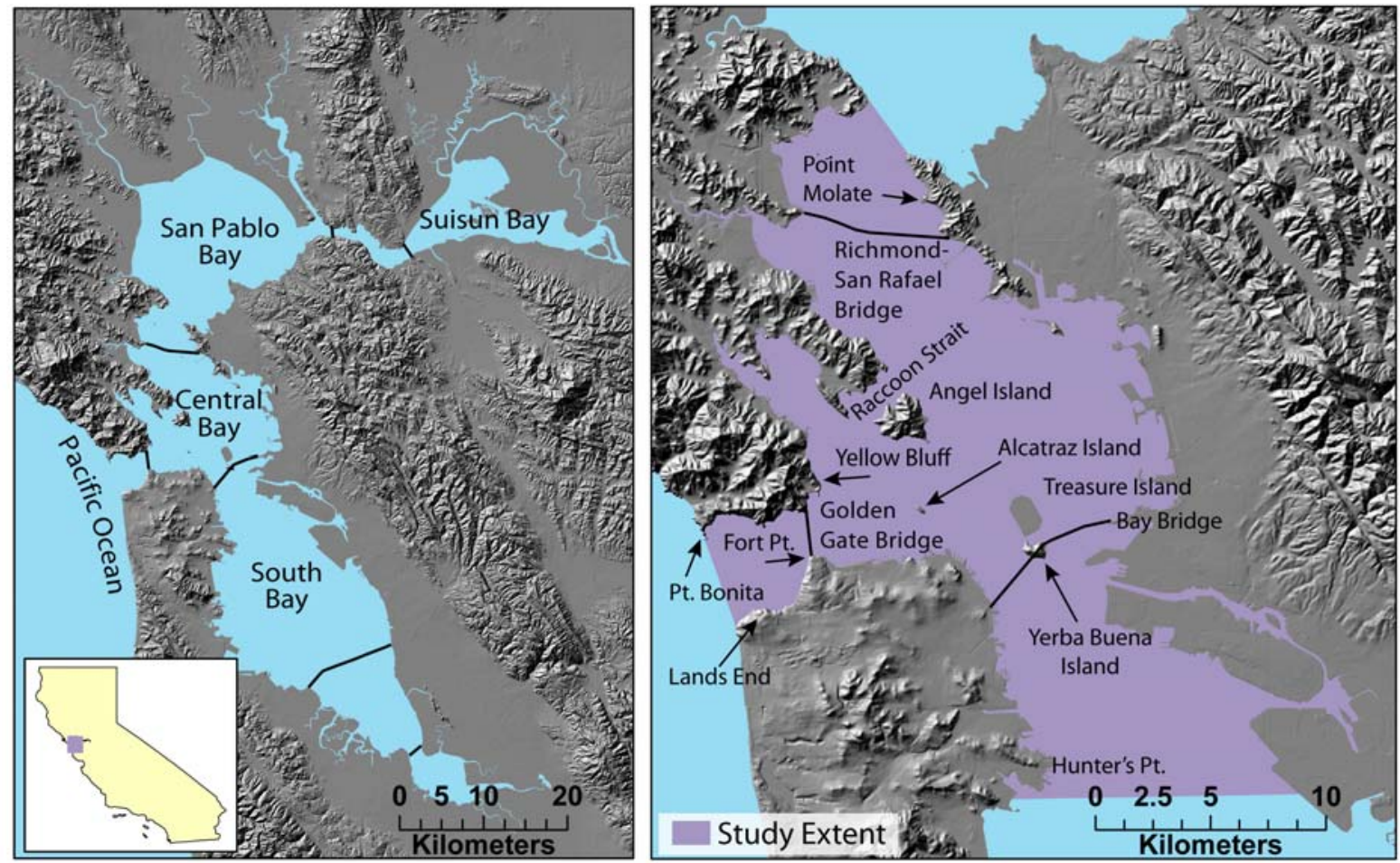

Figure 1. Maps showing location of study area. The figure on the left is of the entire San Francisco Bay estuary, and the figure on the right is a close up of Central San Francisco Bay. 
Changes, both natural and anthropogenic, in the bathymetry of Central San Francisco Bay from 1855 to 1979 were documented by a series of hydrographic and topographic surveys. Utilizing geographic information systems (GIS), it is possible to conduct detailed analyses of these historical surveys to assess not only spatial and temporal trends, but also to quantify changes in net sediment volumes and rates over greater-than-decadal time scales.

This study is the fourth in a series that documents historical bathymetric change and the deposition and erosion of sediment in San Francisco Bay see Jaffe and others, 1998; Cappiella and others, 1999; Foxgrover and others, 2004; Jaffe and others, 2007; U. S. Geological Survey San Francisco Bay Bathymetry Web site. The study area for this report is Central San Francisco Bay, which is defined based on the data gap in our previous studies as the area South of San Pablo Bay, north of Hunter's Point, and east of Point Bonita and Lands End in the Golden Gate. The National Ocean Service (NOS) (formerly the United States Coast and Geodetic Survey (USCGS)) collected five hydrographic surveys of Central San Francisco Bay from 1855 to 1979 that serve as the basis for these models.

More than 700,000 soundings, associated contours, and shorelines were analyzed to produce the bathymetric surfaces. Analyses of long-term trends in the deposition and erosion of sediment provide insight into a dynamic system that is difficult to gain with short-term field studies. Using these data, it is possible to investigate how the documented changes in bathymetry relate to changing biological communities, contaminant issues, and human influences within this estuary.

\section{Methods and Data}

Bathymetric soundings were digitized either from the original USCGS and NOS hydrographic sheets (H-sheets) (fig. 2) or obtained digitally from the National Geophysical Data Center's (NGDC's) Geophysical Data System (GEODAS) database (National Geophysical Data Center, 1996). Bathymetric contours were digitized either from the H-sheets directly or hand drawn on the basis of sounding values. Supplementary contours were manually added to the 1850s intertidal flats where the original sounding values were omitted from the H-sheets. An additional contour was added to all of the surveys, parallel to the shoreline, $20 \mathrm{~m}$ within the bay, to ensure realistic nearshore morphology in areas where soundings were not available (see "Contours" section below). Shoreline and marsh data were taken from topographic sheets (T-sheets). Once all of the information was converted into a digital format, it was georeferenced, or assigned real world coordinates, and combined into a GIS. Continuous surface representations (bathymetric grids) with a horizontal resolution of $25 \mathrm{~m}$ were generated for each of the five hydrographic surveys using ArcInfo’s TopoGrid module. TopoGrid is a modeling algorithm specifically designed to utilize both point and contour data to retain proper hydrogeomorphic properties. To ensure high-quality bathymetric grids, error checking techniques were applied at various stages of data processing. 


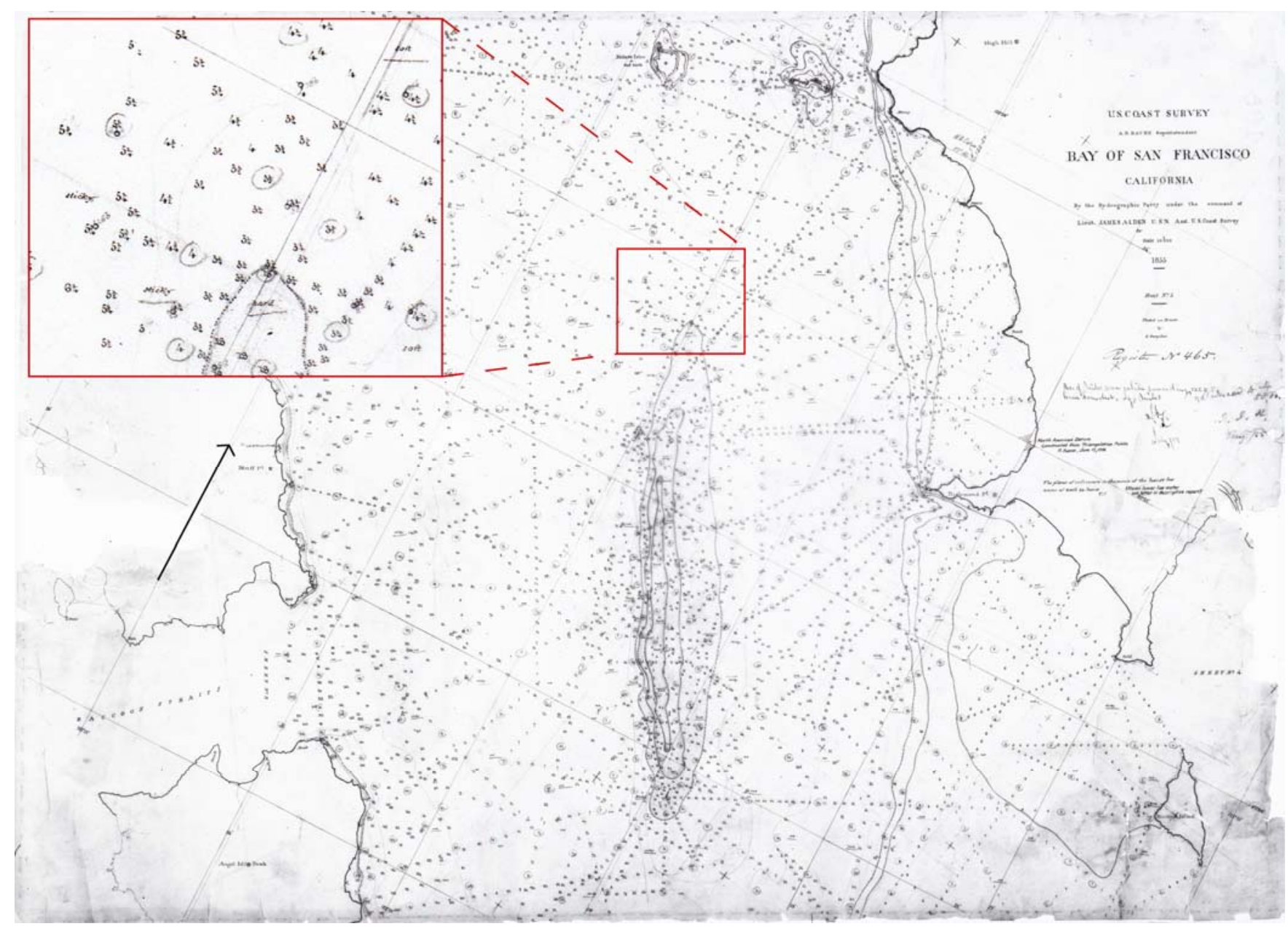

Figure 2. Example of an $1858 \mathrm{H}$-sheet. The data density and distribution are typical of the 1850 s hydrographic surveys.

Before conducting analyses of sediment deposition and erosion, we converted all of the grids to a common vertical datum (MLLW for the 1941-1959 tidal epoch) to account for changes in sea level over the 125-year span of the surveys. The grids were also adjusted to account for an interpolation bias introduced from the gridding algorithms (see "Correcting Grid Error" section below). Deposition and erosion that occurred within consecutive periods was then computed by differencing the corrected grids. The amount of sediment eroded and deposited between periods was calculated on a cell-by-cell basis to quantify net sediment volume change and rates of change throughout the bay. 


\title{
Bathymetric Time Series
}

\author{
Input Data
}

1850s

Soundings for the 1850s surveys were manually digitized from scanned images of H-sheets obtained from the Hydrographic Surveys Division of the NOS (table 1). Hand-drawn depth contours based upon $\mathrm{H}$-sheet data were digitized and supplemented manually as needed to maintain a consistent contour interval throughout all of the surveys (fig. 3). The shorelines, as well as the marsh boundaries for the 1850s surveys, were obtained digitally from the San Francisco Estuary Institute's (SFEI) EcoAtlas (1998).

Table 1. of 1850s H-sheets of Central San Francisco Bay

\begin{tabular}{||c|c|c|c||}
\hline H-Sheet & Year & Scale & Soundings \\
\hline \multicolumn{4}{|c||}{} \\
\hline H462 & 1855 & $1: 10,000$ & 2,551 \\
\hline H463 & 1855 & $1: 10,000$ & 1,378 \\
\hline H464 & $1853-1854$ & $1: 10,000$ & 6,722 \\
\hline H465 & 1855 & $1: 10,000$ & 3,794 \\
\hline H466 & 1855 & $1: 10,000$ & 2,984 \\
\hline H573 & 1857 & $1: 10,000$ & 2,333 \\
\hline H628 & $1857-1858$ & $1: 20,000$ & 1,290 \\
\hline & & & Total $=21,052$ \\
\hline
\end{tabular}
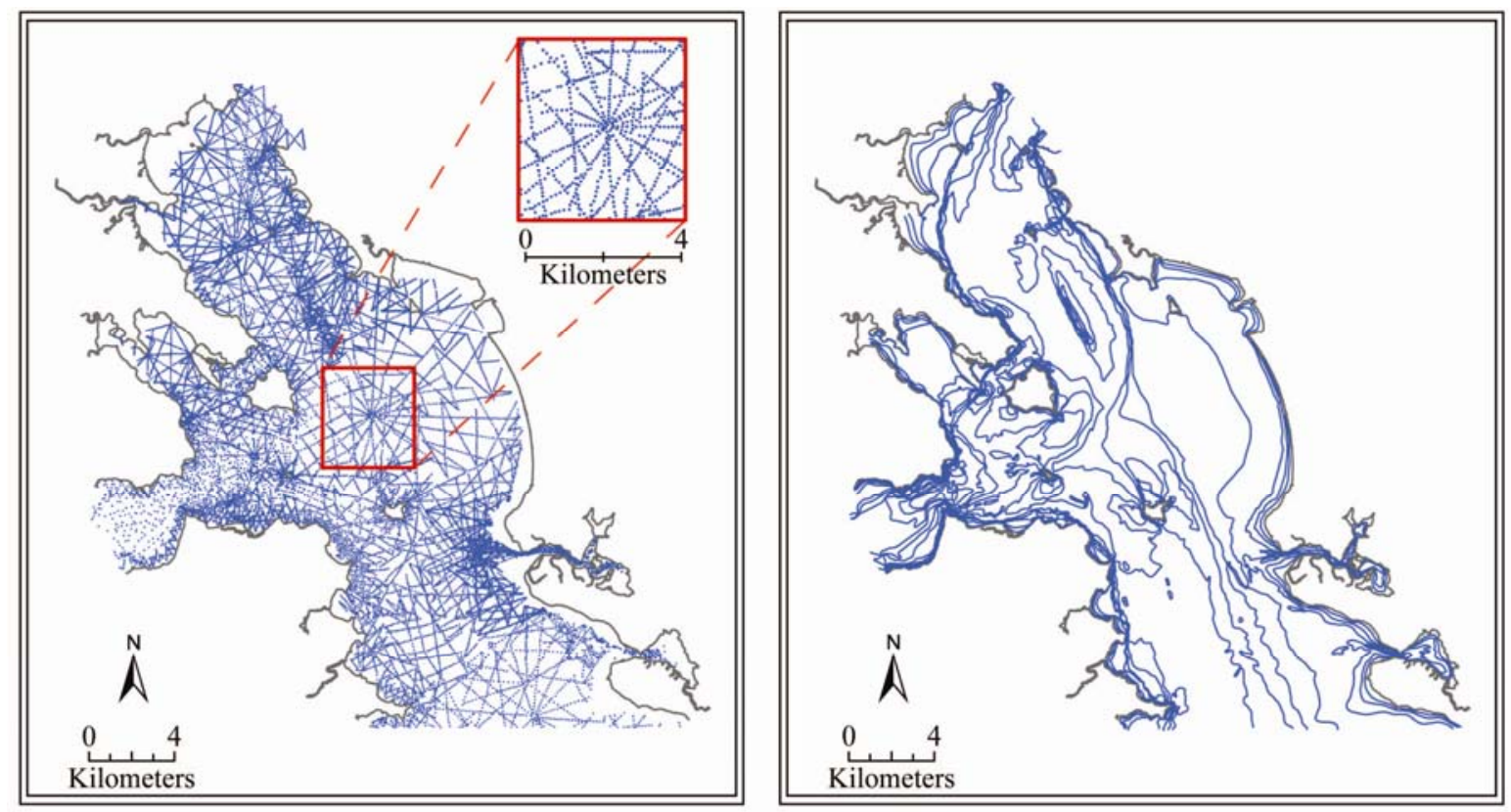

Figure 3. Maps showing 1850s soundings (left) and contours (right) used for surface modeling. 
It was common practice on the earliest H-sheets for all soundings above Mean Lower Low Water (MLLW) to be assigned a blanket value of zero (Dedrick, 1983). This was a result of USCGS plotting standards at that time and does not accurately reflect the slope of the intertidal flats. To create a more realistic slope in this region, we artificially generated contours at approximately $1 / 2$ and $1 / 4$ of the distance between the shoreline, represented by Mean High Water (MHW), and MLLW. These contours were assigned values of 25 percent and 50 percent, respectively, of Mean Tide Level (MTL) elevations (see "Contours" section below). All zero soundings between MLLW and MHW were removed from the gridding routine. This methodology produced a rough estimate of tidal flat slope based upon 1895 surveys in which soundings above MLLW were retained.

Due to the relatively sparse distribution of data in the 1850s surveys, it was necessary to add a limited number of supplementary soundings (based upon 1890s data and surrounding sounding values) to narrow channels crossing the intertidal flats in order to maintain channel connectivity through the shallow reaches.

1890s

Soundings for the 1890s surveys were manually digitized from scanned images of H-sheets obtained from the Hydrographic Surveys Division of the NOS (table 2). Hand-drawn depth contours were digitized based upon H-sheet data and supplemented manually as needed to maintain a consistent contour interval throughout all of the surveys (fig. 4).

Table 2. Table of 1890s H-sheets of Central San Francisco Bay.

\begin{tabular}{||l|c|c|c||}
\hline H-Sheet & Year & Scale & Soundings \\
\hline \multicolumn{4}{|c||}{} \\
\hline H2244 & 1895 & $1: 10,000$ & 13,200 \\
\hline H2246 & 1896 & $1: 10,000$ & 28,946 \\
\hline H2254 & $1895-96$ & $1: 10,000$ & 160,279 \\
\hline H2283 & $1894-1897$ & $1: 10,000$ & 10,713 \\
\hline H2301 & $1895-1897$ & $1: 10,000$ & 18,525 \\
\hline H2310 & 1896 & $1: 10,000$ & 5,148 \\
\hline H2315 & 1897 & $1: 20,000$ & 8,464 \\
\hline H2340 & $1895-1897$ & $1: 10,000$ & 14,950 \\
\hline H2510 & $1899-1901$ & $1: 10,000$ & 14,361 \\
\hline H2513 & $1900-1901$ & $1: 10,000$ & 14,696 \\
\hline & & & Total = 289,282 \\
\hline
\end{tabular}



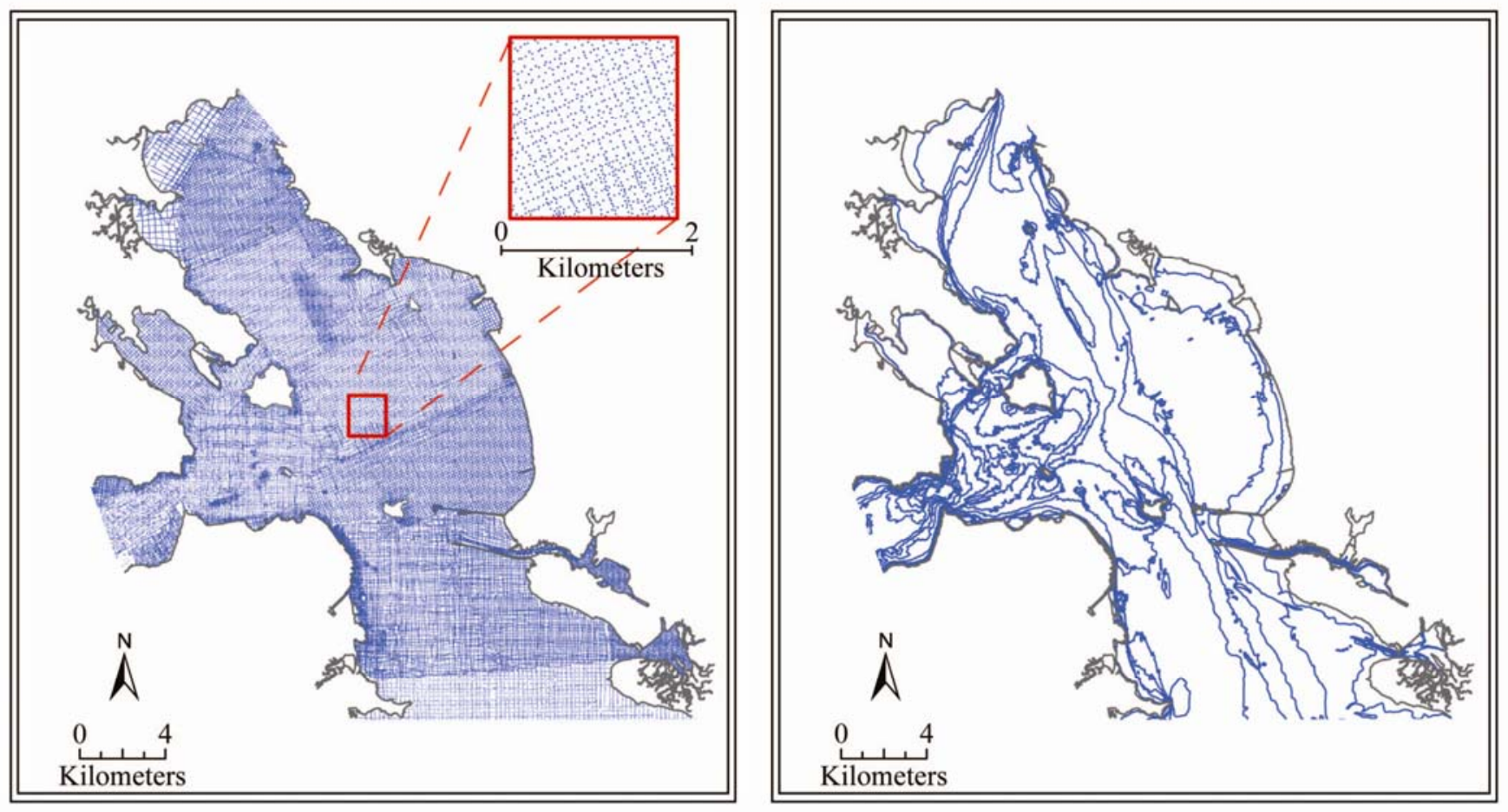

Figure 4. Maps showing 1890s soundings (left) and contours (right) used for surface modeling.

The shorelines and the marsh boundaries were digitized from scanned images of T-sheets that were created during the same period as the H-sheets. The T-sheets were obtained from the NOAA National Ocean Service Coastal Services Center.

1920s

Soundings for the 1920s surveys were manually digitized from scanned images of H-sheets obtained from the Hydrographic Surveys Division of the NOS (table 3). Hand-drawn depth contours were digitized based upon $\mathrm{H}$-sheet data and supplemented manually as needed to maintain a consistent contour interval throughout all of the surveys (fig. 5).

Table 3. Table of 1920s H-sheets of Central San Francisco Bay.

\begin{tabular}{||c|c|c|c||}
\hline H-Sheet & Year & Scale & Soundings \\
\hline \multicolumn{3}{|c||}{} \\
\hline H3929 & $1916-1931$ & $1: 20,000$ & 5,503 \\
\hline H3928 & $1916-1925$ & $1: 20,000$ & 19,104 \\
\hline H4137 & $1919-1920$ & $1: 20,000$ & 23,509 \\
\hline & & & Total = 48,116 \\
\hline
\end{tabular}



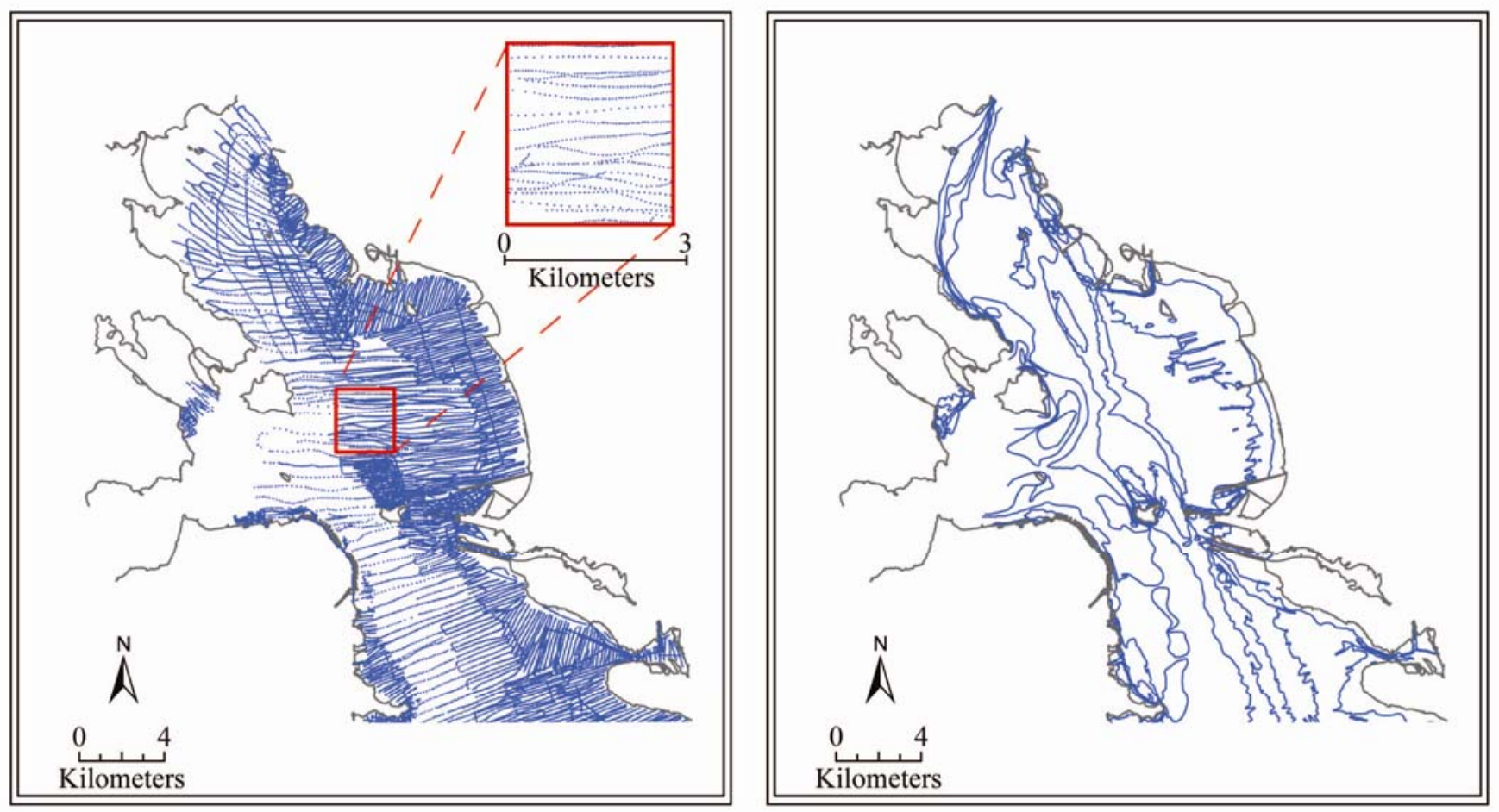

Figure 5. Maps showing 1920s soundings (left) and contours (right) used for surface modeling.

The shorelines and the marsh boundaries were digitized from scanned images of T-sheets. The 1920s survey is the only time period that does not have a complete topographic survey to complement the hydrographic survey. As a result, parts of the shoreline and marsh areas have been supplemented with data from the 1890s or 1950s surveys (fig. 6). 


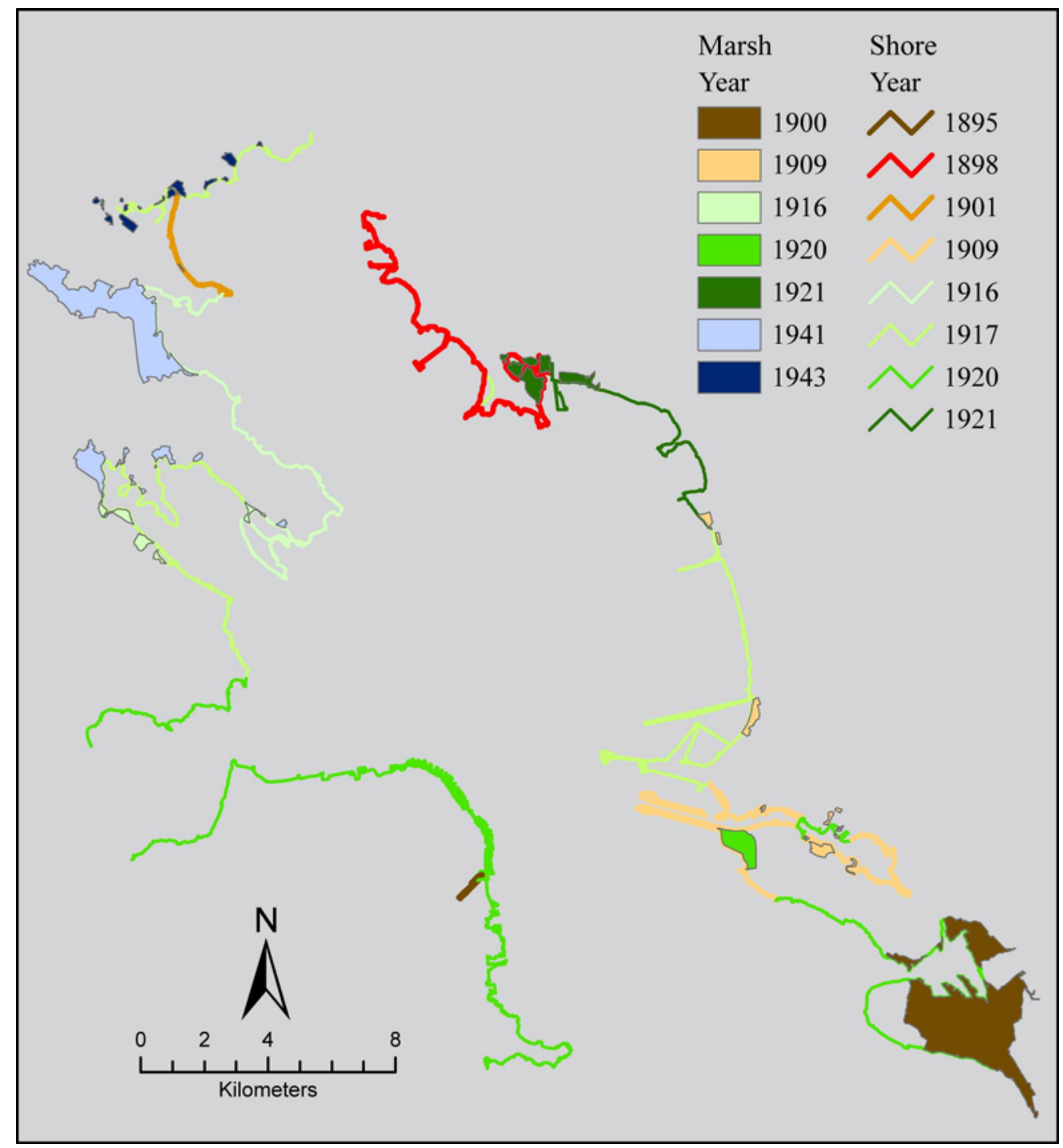

Figure 6. Map showing 1920s shoreline and marsh data augmented with information from earlier and later surveys.

Although we generally label our bathymetric maps with a single year, hydrographic surveys customarily are conducted over the span of a few years. Normally the survey area is partitioned into many smaller surveys, (indicated by the numerous $\mathrm{H}$-sheets) that are generally completed within one to two years. The year displayed on our maps is the year in which the majority of the surveys were conducted. The 1920s survey, comprising three H-sheets, spanned 17 years, with one $\mathrm{H}$-sheet covering a span of 15 years. For this time period the H-sheets cover much larger areas and time spans than in previous surveys.

The 1920s survey is unique in that it is the only one that did not cover the entirety of Central San Francisco Bay. During this time period it was decided to focus on wire drag surveys in an effort to locate and eliminate any obstructions to navigations that existed in the Golden Gate and the main shipping passages around Angel Island and Alcatraz Island. As a result, many of the 1920s H-sheets do not contain shorelines. For all other survey periods the shoreline was drawn on the smooth sheet before plotting the soundings. The lack of a shoreline is noted in descriptive reports for survey H3928 and cited 
as a possible reason that some errors were made in locating soundings. The descriptive reports for surveys H3928 and H3929 highlight other problems with these surveys. Issue was made of the illegibility of soundings in the records book, improper recording techniques of a sounding's location and time, and leadline corrections entered in the wrong columns (Department of Commerce Coast and Geodetic Survey, 1917).

The orientation and spacing of tracklines and soundings are also different from those in other post-1850s surveys. On the 1890s H-sheets, the average distance between tracklines is 150 meters, with soundings spaced an average of 60 meters apart. In the 1950s H-sheets, the average trackline spacing is 100 meters, with soundings spaced an average of 30 meters apart. However, on the 1920s H-sheets, the trackline spacing ranges from 100 meters to more than 1 kilometer. The spacing of soundings also varies greatly from as close as 30 meters to upwards of 400 meters apart.

1940s-1950s

Depth soundings for the 1940s-1950s surveys were obtained digitally from the National Geophysical Data Center's GEODAS database (table 4). Depth contours were digitized from H-sheets and supplemented with hand-drawn contours as needed to maintain a consistent contour interval throughout all of the surveys (fig. 7).

Table 4. Table of 1940s-1950s H-sheets of Central San Francisco Bay.

\begin{tabular}{||l|c|l|c||}
\hline H-Sheet & Year & \multicolumn{1}{|c||}{ Scale } & Soundings \\
\hline \multicolumn{4}{|l||}{} \\
\hline H6421 & 1938 & $1: 5,000$ & 959 \\
\hline H7619 & 1947,1950 & $1: 10,000$ & 17,674 \\
\hline H7620 & 1947 & $1 ; 10,000$ & 17,526 \\
\hline H7621 & $1947-1948$ & $1: 10,000$ & 27,785 \\
\hline H7622 & 1947 & $1: 5,000$ & 22,124 \\
\hline H7623 & 1947 & $1: 5,000$ & 5,911 \\
\hline H7704 & 1948 & $1: 10,000$ & 10,413 \\
\hline H7705 & 1948 & $1: 10,000$ & 15,652 \\
\hline H7706 & 1949 & $1: 5,000$ & 3,215 \\
\hline H7716 & 1948 & $1: 5,000$ & 6,092 \\
\hline H7717 & 1948 & $1: 2,400$ & 8,652 \\
\hline H7867 & 1950 & $1: 10,000$ & 11,407 \\
\hline H7868 & 1951 & $1: 2,500$ & 1,445 \\
\hline H7897 & 1947 & $1: 10,000$ & 9,524 \\
\hline H8023 & 1954 & $1: 5,000$ & 7,651 \\
\hline H8024 & 1954 & $1: 10,000$ & 20,123 \\
\hline H8025 & $1954-1955$ & $1: 10,000$ & 13,137 \\
\hline H8027 & 1955 & $1: 20,000$ & 12,900 \\
\hline H8028 & 1956 & $1: 20,000$ & 17,361 \\
\hline & & & Total = 229,551 \\
\hline
\end{tabular}



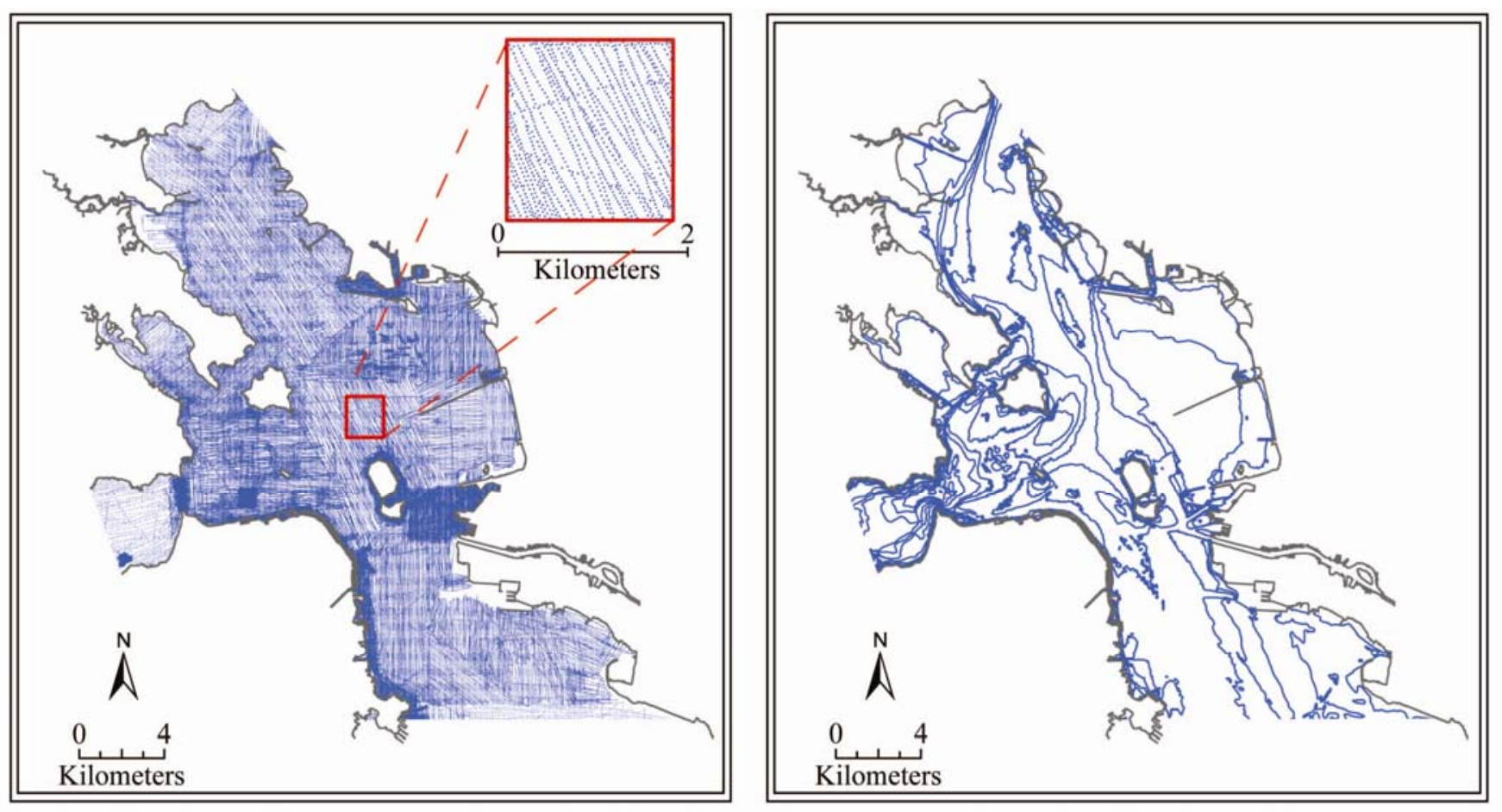

Figure 7. Maps showing 1940s and 1950s soundings (left) and contours (right) used for surface modeling.

The shorelines for the 1940s and 1950s surveys were taken from the San Francisco Bay Shoreline Digitization Project completed by NOAA (Rink, 2003). The marsh was digitized from the Tsheets provided with the project. The project did not include the southernmost portions the Central San Francisco Bay survey. Therefore, the shorelines for that area were taken from the H-sheets and do not contain marsh information.

1980s

Digital soundings for the 1980s surveys were obtained from NGDC's GEODAS database (table 5). Hand-drawn depth contours were digitized based upon depth soundings (fig. 8). The shorelines and the marsh boundaries were obtained digitally from SFEI’s EcoAtlas. 
Table 5. Table of 1980s H-sheets of Central San Francisco Bay.

\begin{tabular}{|c|c|c|c|}
\hline H-Sheet & Year & Scale & Soundings \\
\hline H9185 & 1971 & $1: 5,000$ & 7,366 \\
\hline H9793 & 1978 & $1: 10,000$ & 21,942 \\
\hline H9794 & 1978 & $1: 10,000$ & 27,732 \\
\hline H9810 & 1979 & 1:10,000 & 12,532 \\
\hline H9811 & 1979 & $1: 10,000$ & 18,204 \\
\hline H9819 & 1979 & $1: 10,000$ & 19,643 \\
\hline H9844 & 1979-1981 & $1: 10,000$ & 30,133 \\
\hline H9869 & 1980 & $1: 10,000$ & 12,726 \\
\hline H9873 & 1980-1981 & $1: 5,000$ & 4,497 \\
\hline H9927 & 1983 & $1: 5,000$ & 4,327 \\
\hline $\mathrm{H} 10080$ & 1983 & $1: 10,000$ & 18,042 \\
\hline & & & Total $=177,144$ \\
\hline
\end{tabular}
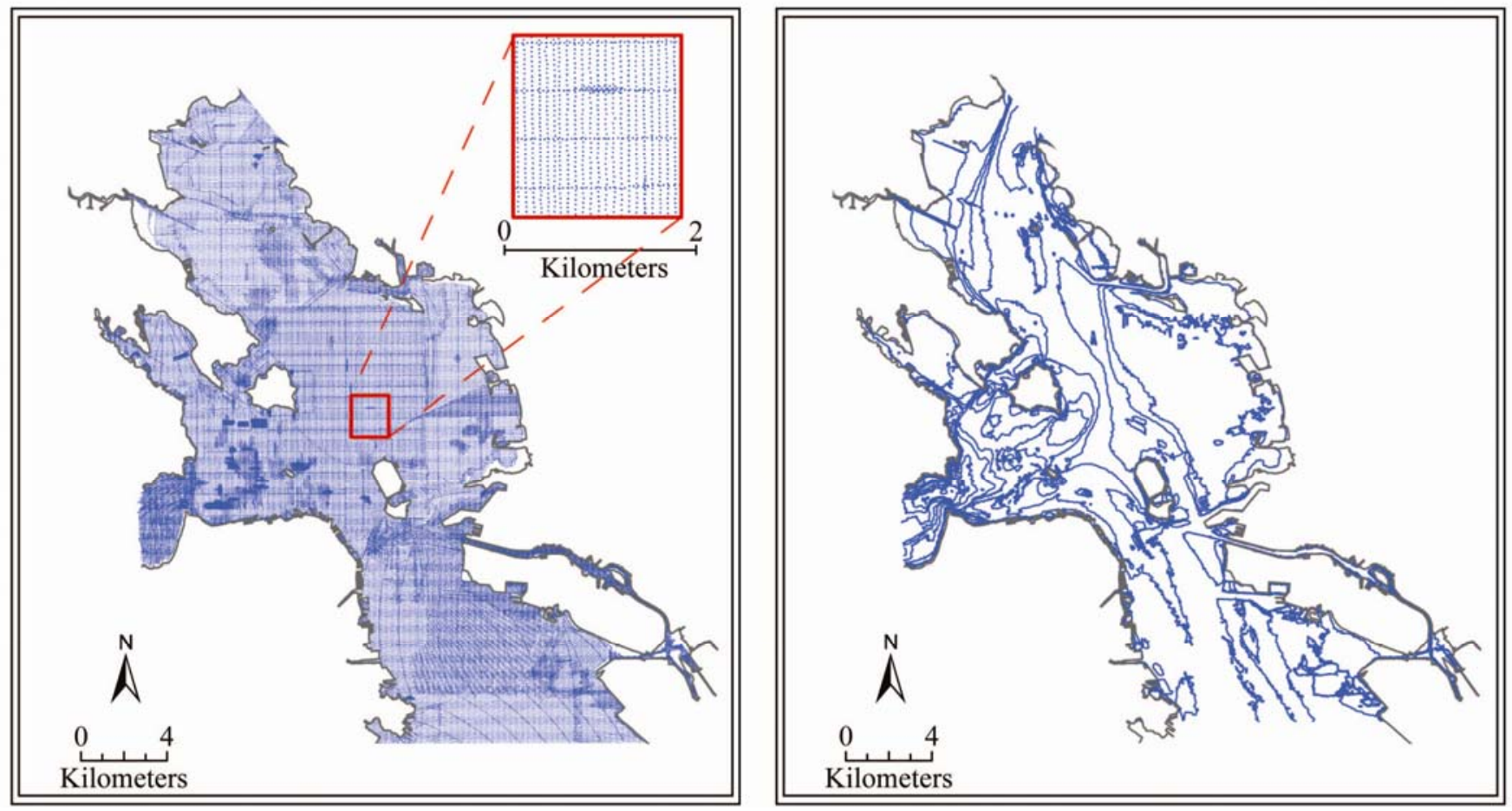

Figure 8. Maps showing 1980s soundings (left) and contours (right) used for surface modeling.

\section{Georeferencing}

Georeferencing the early surveys was especially challenging because the 1850s hydrographic sheets did not contain consistent graticules or coordinate information. What they do contain are triangulation stations that still existed during the 1890s survey and are present on the 1890s H-sheets 
and T-sheets. In all, a total of 36 common stations were located. Using ArcMap’s georeferencing tools, scanned images of the unregistered 1850s H-sheets and T-sheets were linked to the 1890s H-sheets (which had already been georeferenced) by control points at the common triangulation stations. The real-world coordinates for the control points were then used to register the 1850s digitized coverages.

The 1890s H-sheets and T-sheets contain graticules depicting longitude and latitude referenced to a localized datum. To determine the relation of this local datum to the established North American Datum 1927 (NAD27), the sheets were registered using published coordinate values of four triangulation stations throughout the bay (Mitchell, 1936). Based upon these coordinates, a standard correction shift was calculated and applied to the graticule values displayed on the published 1890s Hsheets and T-sheets.

The two H-sheets digitized for the Central San Francisco Bay 1920s survey do not reference the same local datum as the 1890s H-sheets, nor are they corrected for NAD27. For these sheets, an average offset between their datum and the one displayed on the 1890s sheets was derived from three triangulation stations found in common between 1890s and the 1920s H-sheets. The T-sheets for this period alternate between being best registered with the 1890s shift and with the 1920s shift. The determination of which was better was made by comparing the outputs to hard features (for example, piers, buildings) in the 1890s registered data.

H-sheets and T-sheets from the 1950s and 1980s surveys are properly referenced to NAD27 on the original maps and were easily reprojected to the desired Universal Transverse Mercator (UTM) North American Datum 1983 (NAD83) coordinates using ArcGIS.

\section{Contours}

Depth contours assist in defining the general morphology of the bathymetric grids and stabilize the model in areas of sparse soundings. Contours were digitized from H-sheets at 0, 6, 12, 18, 30, 60, 90, 120, 180, 240, 300, and 360 feet below MLLW. Depth contours for surveys up to and including the 1950s surveys were digitized from $\mathrm{H}$-sheets and supplemented as needed to maintain a consistent contour interval throughout all of the surveys. Depth contours for the 1980s surveys were added manually based upon sounding values. In general, depth contours were only drawn in areas supported by a minimum of three soundings.

In many areas, there are gaps in excess of $150 \mathrm{~m}$ between the shallowest soundings and the shoreline. In order to best model the steep slope of the intertidal flat as it approaches the shoreline in areas where soundings do not exist within the first two grid cells (50 $\mathrm{m}$ from shore), an additional contour has been placed parallel to the shoreline at a distance of $20 \mathrm{~m}$ within the bay, and assigned an approximate value of mean tide level (MTL). The MTL values were derived from tidal stations around the perimeter of the bay and interpolated between stations to assign a continuous elevation value to the shoreline buffer. This provides a means of modeling the steep slope of the nearshore morphology within the confines of a 25-m grid cell but may not be an accurate reflection of nearshore morphology.

\section{Shorelines}

All of the shorelines used for this study were originally derived from T-sheets and are defined as the MHW line. For modeling purposes, it was necessary to assign an elevation to this boundary. Due to the tidal dynamics of Central San Francisco Bay, MHW values vary by location. In order to reflect this variation, MHW values were derived from various tidal stations around the perimeter of the bay and interpolated between stations to assign continuous elevation values to the shorelines (fig. 9). It is 
important to note that while this assignment of shoreline elevations is sufficient for our modeling purposes, it is not intended to provide specific MHW values at any given location.

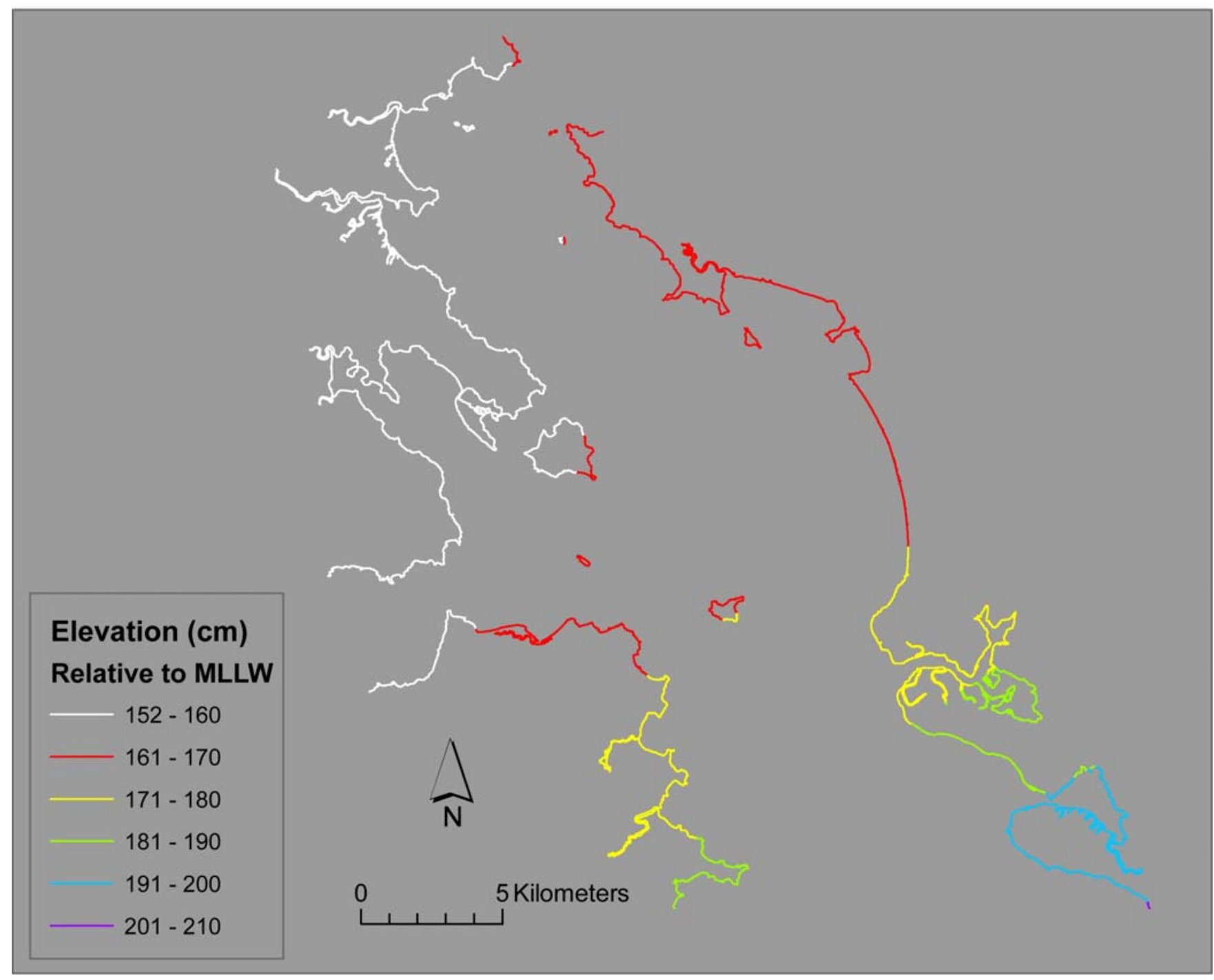

Figure 9. Map showing Mean High Water (MHW) values assigned to the 1855 shoreline.

\section{Surface Modeling}

Once the data were combined into a GIS, units were converted from feet to centimeters. Then we used ArcInfo's TopoGrid module to generate a continuous surface representation (25-m horizontal resolution) of each bathymetric survey. TopoGrid is a gridding algorithm designed to utilize both sounding and contour data to generate a hydrologically correct Digital Elevation Model (DEM). TopoGrid uses an iterative finite difference interpolation technique in which the contours are initially used to build a generalized drainage model that is further refined using both soundings and contour values to determine elevation values at each cell. Each historical bathymetric survey grid is defined more than 400,000 grid cells. Bathymetry in tributary channels less than $150 \mathrm{~m}$ wide were excluded because they could not be accurately modeled at a resolution of $25 \mathrm{~m}$. 


\section{Correcting Grid Error}

Error checking is an iterative procedure that took place at multiple stages of data processing. An initial round of error checking was conducted through visual inspection in ArcMap once all of the data had been combined into a GIS. Point data were classified by elevation in feet. Class boundaries were chosen to correspond with the contour interval (for example, 0 to 6, 7 to 12, and 13 to 18). Contrasting colors were then used to shade the point data (fig. 10). Large errors (for example, a decimal point off, attribute typos) tend to stand out and can be detected in this way. Contours were also checked for agreement with the point data (such as all the green points should be on one side of the contour, all the blue points on the other).

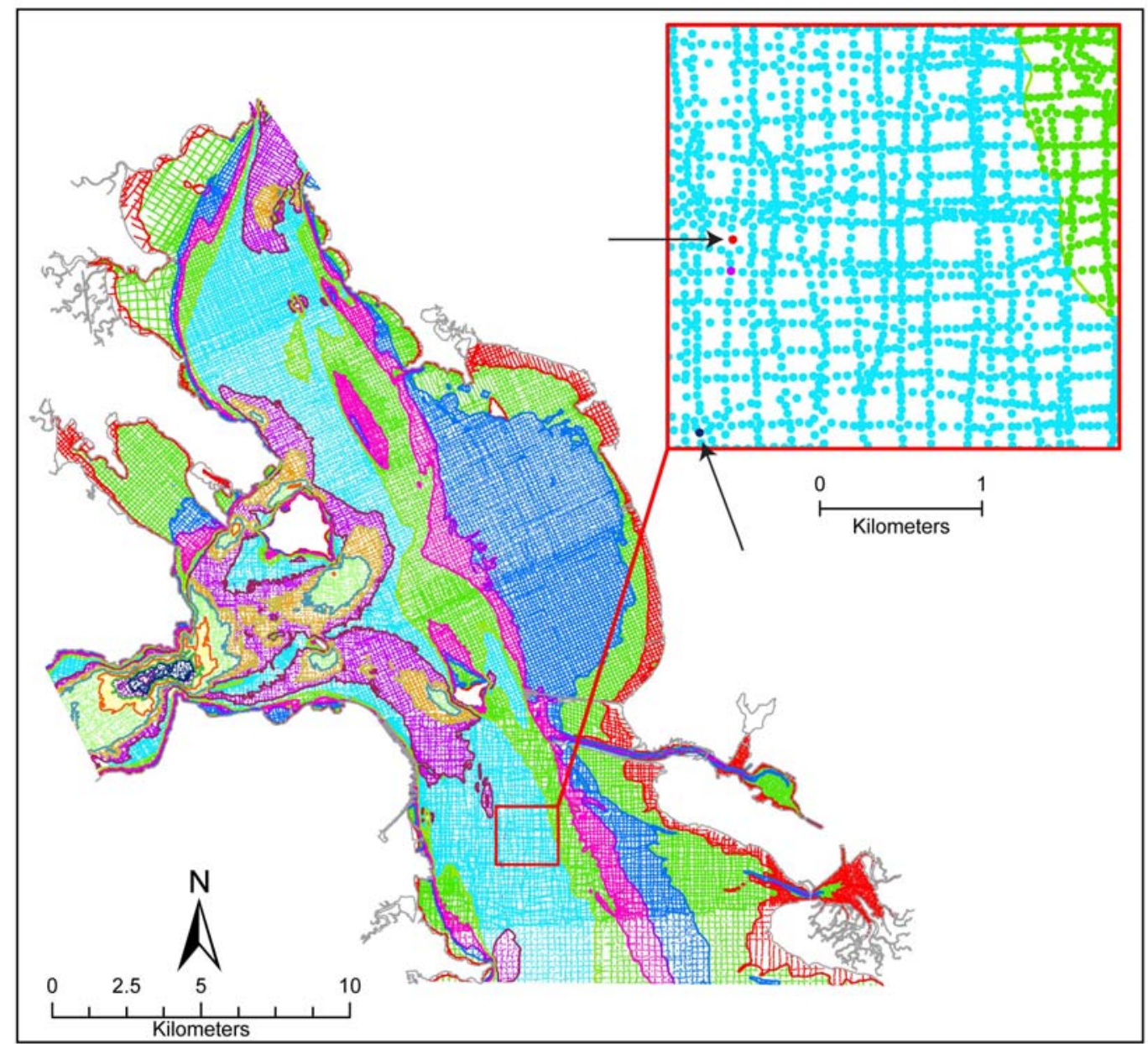

Figure 10. Map showing example of visual error checking technique applied to both soundings and contours. Arrows indicate outliers that were removed after inspecting surrounding soundings to confirm that the data were erroneous.

A secondary visual inspection was performed after the first round of grid production. The bathymetric grid from each time series was hill-shaded to accentuate any abnormalities in the morphology of the bay floor. For example, erroneous soundings may appear as abnormal pits or mounds relative to the surrounding data. Erroneous soundings were either corrected or removed from the input data. 
The final-error checking step utilized a script designed to compare the value of each individual sounding to the corresponding cell value in the bathymetric grid. The difference between soundings and corresponding grid cells is useful in identifying areas of error, and also serves as a means for quantifying how well the surface represents the original point data. When the difference value is positive, the grid value is deeper than the sounding value, and when the difference is negative, the sounding value is deeper (fig. 11). Graphs were made to compare the difference values with localized slope and depth. These graphs made it easier to pick out erroneous sounding values and soundings that could not be resolved within the specified cell size. The greatest differences in individual soundings and cell values occurred along the steep and variable slopes in the Golden Gate, Raccoon Strait, and in the areas surrounding Angel Island and Alcatraz Island where large gradients in bathymetry could not be resolved within a single 25-m grid cell. 


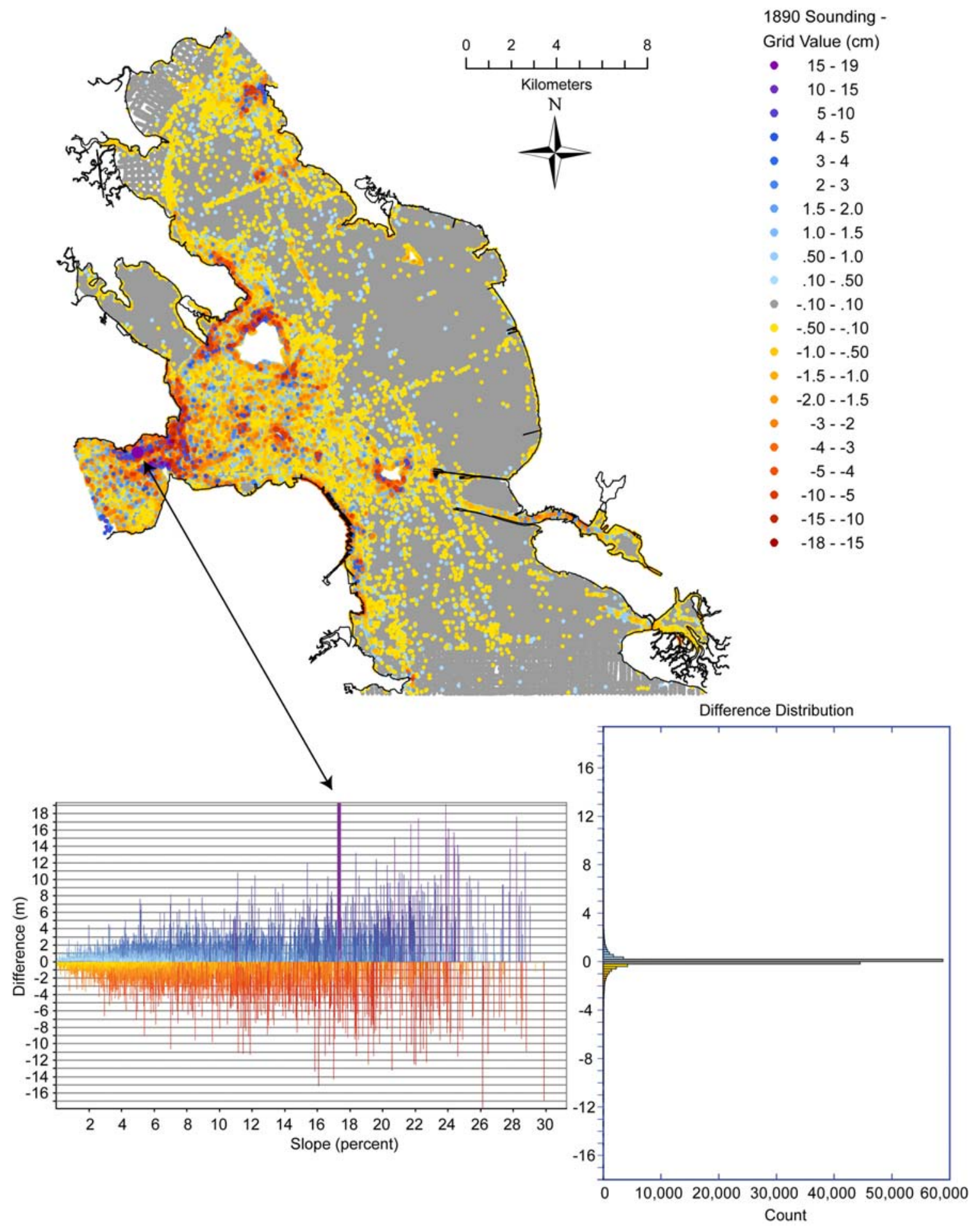

Figure 11. Method for determining incorrectly entered sounding values by locating soundings with large differences from the grid value and comparing them to adjacent soundings. The graph on the bottom left showing difference in grid value and sounding value versus slope is used to locate outliers on the map. A sounding is compared to adjacent soundings to determine if there was a data input error, in which case it is removed. The distribution chart shows that the vast majority of sounding and grid values fall within acceptable levels of difference of plus or minus $10 \mathrm{~cm}$. 
The above scripting method also led to the use of a 25-meter grid cell instead of the 50-meter size used in creation of the South San Francisco Bay study (Foxgrover and others, 2004). The complexity of the Central Bay bathymetry and steeper slopes led to larger errors than in South San Francisco Bay. In an effort to mitigate those errors, we choose to use 25-meter grid cells for this study. The 25-meter grid lowered the mean difference between soundings and grid cells in the 1950s and 1980s surveys and slightly raised the mean for the previous years. However, the 25-meter grid reduced the standard deviation for all survey years. With the reduction in the standard deviation for all years, better results in the later year surveys, and small change in mean in the earlier years, the 25-meter grid size is justified.

After the error-checking process was complete and the soundings were finalized, new bathymetric grids were generated. The difference script was run on these new grids, with the average difference from each grid now representing bias in the bathymetry grid that results from the gridding algorithm and selected resolution (table 6). A mean negative bias indicates that the bathymetry grid is on average shallower than the original sounding values and a mean positive bias indicates the grid is trending deeper than the soundings. There is some spatial variability in the bias, with larger errors often occurring in areas of steeper slopes where it was harder for the grid to resolve the depth within a 25meter-sized grid cell, but these areas are fairly well distributed throughout the entire project area. The bias table revealed that all of the grids were underestimating depths. Before performing the volume calculations, the mean bias for each survey period was removed from the grids by adding the value of the bias to each grid.

Table 6. Table of grid bias, representing difference between sounding values and corresponding grid cells. This serves as a proxy for how well the surface represents the original sounding data.

\begin{tabular}{|c|c|c|c|c|c|c|c|c|c|}
\hline Year & Frequency & \multicolumn{2}{|c|}{ Maximum } & \multicolumn{2}{|c|}{ Minimum } & \multicolumn{2}{|c|}{ Mean } & \multicolumn{2}{|c|}{ Std. Deviation } \\
\hline & & (cm) & $(\mathrm{ft})$ & (cm) & (ft) & (cm) & $(\mathrm{ft})$ & $(\mathrm{cm})$ & $(\mathrm{ft})$ \\
\hline 1855 & 18,884 & 1,859 & 63.80 & $-1,945$ & -63.80 & -3.4 & -0.11 & 102.8 & 3.34 \\
\hline 1895 & 119,334 & 1,933 & 63.42 & $-1,788$ & -58.68 & -2.5 & -0.08 & 70.4 & 2.31 \\
\hline 1920 & 30,639 & 676 & 22.18 & -984 & -32.28 & -4.5 & -0.15 & 42.3 & 1.39 \\
\hline 1947 & 169,552 & 1,653 & 54.23 & $-1,795$ & -58.90 & -0.4 & -0.01 & 95.8 & 3.14 \\
\hline 1979 & 124,895 & 1,414 & 46.39 & $-1,713$ & -56.19 & -5.4 & -0.18 & 90.1 & 2.95 \\
\hline
\end{tabular}

\section{Sediment Volume Change Analysis}

Before conducting analyses of sediment deposition and erosion, the grids were adjusted to bring all of the surveys to a common vertical datum. Once these adjustments were made, the corrected grids were differenced to reveal deposition and erosion that occurred during consecutive surveys.

\section{Vertical Datum Adjustment}

The USCGS and NOS hydrographic surveys are relative to the MLLW vertical datum. The MLLW datum is the average of the lower low water height of each tidal day observed at a given tidal station over the National Tidal Datum Epoch, a specific 19-year cycle (18.6-year tidal epoch rounded to a full year to minimize bias from seasonal variation). The MLLW tidal datum, therefore, varies 
depending upon the 19-year cycle used for reference. Before generating sediment volume change calculations, all of the bathymetric grids were adjusted to a common vertical datum to account for changing survey datums accompanying fluctuations in sea level over the 125-year span of the surveys.

During the time span of this study (1853-1983), five tidal datum epochs were used for the tide station at San Francisco (Golden Gate).The 19-year cycle from 1941-1959 was used to calculate MLLW values for the most recent (1978-1983) hydrographic surveys in Central San Francisco Bay. Earlier epochs used for San Francisco include 1855—73, 1878_-96, 1898—1916, and 1924—42. The epoch used as the vertical datum reference for hydrographic surveys was presumed to be the 19-year cycle most recently preceding the date of the survey, with the exception of the 1850s surveys for which there was no previously established tidal epoch.

Assuming no change in the bathymetry, an increase in the height of the tidal datum between surveys would result in a sounding from the later survey appearing deeper than a sounding at the same location from the earlier survey. An adjustment was derived to bring the historical surfaces to the same vertical datum used for the 1980s surface by differencing the staff reading for MLLW corresponding to a historical survey from the staff reading for MLLW during the 1941-59 epoch (table 7).

Table 7. Vertical Datum Adjustments.

\begin{tabular}{|c|c|c|c|c|c|}
\hline Survey Year & Presumed Epoch & \multicolumn{2}{|c|}{ MLLW on staff } & \multicolumn{2}{|c|}{ Diff. from MLLW 1941-59 } \\
\hline & & (m) & $(\mathrm{ft})$ & (m) & (ft) \\
\hline $1855^{1}$ & N/A & 1.66 & 5.46 & 0.09 & 0.29 \\
\hline 1895 & $1855-73$ & 1.65 & 5.42 & 0.10 & 0.33 \\
\hline 1920 & $1898-16$ & 1.67 & 5.49 & 0.08 & 0.26 \\
\hline 1947 & $1924-42$ & 1.71 & 5.61 & 0.04 & 0.14 \\
\hline 1979 & $1941-59$ & 1.75 & 5.75 & --- & --- \\
\hline
\end{tabular}

${ }^{1}$ 19-year tidal epoch not available for 1855 adjustment. MLLW value calculated by averaging monthly MLLW values over the time in which most surveys were conducted.

We were unable to find any documentation stating how the 1850s surveys were referenced to MLLW. We have assumed that these surveys were referenced to MLLW over the time in which they were collected. For the 1850s, surveys ran from 1853 to 1857, with the majority of the surveys conducted in 1855. Therefore we averaged monthly MLLW values for Fort Point tidal station in 1855 to obtain a tidal correction.

\section{Sediment Volume Change Calculations}

Once all the adjustments were made, maps of deposition and erosion were generated by differencing the corrected bathymetric grids. Multiplying the grids of deposition and erosion by surface area on a cell-by-cell basis resulted in volumetric measurements of sediment change. To improve comparability of sediment volumes for all surveys, maps of deposition and erosion include only those tributary channels that contained bathymetric data for all five time periods. 


\section{Summary of Observations}

Although the primary focus of our study is bathymetry and the deposition and erosion of sediment, we also included an estimate of change in the area of tidal marsh, intertidal flats, and Central San Francisco Bay as a whole. Marsh boundaries were used solely for display purposes and approximations of total marsh area. Changes in marsh are not accounted for in sediment volume change calculations. Figure 12 shows the bathymetry of Central San Francisco Bay as it changes from 1855 to 1979 . 


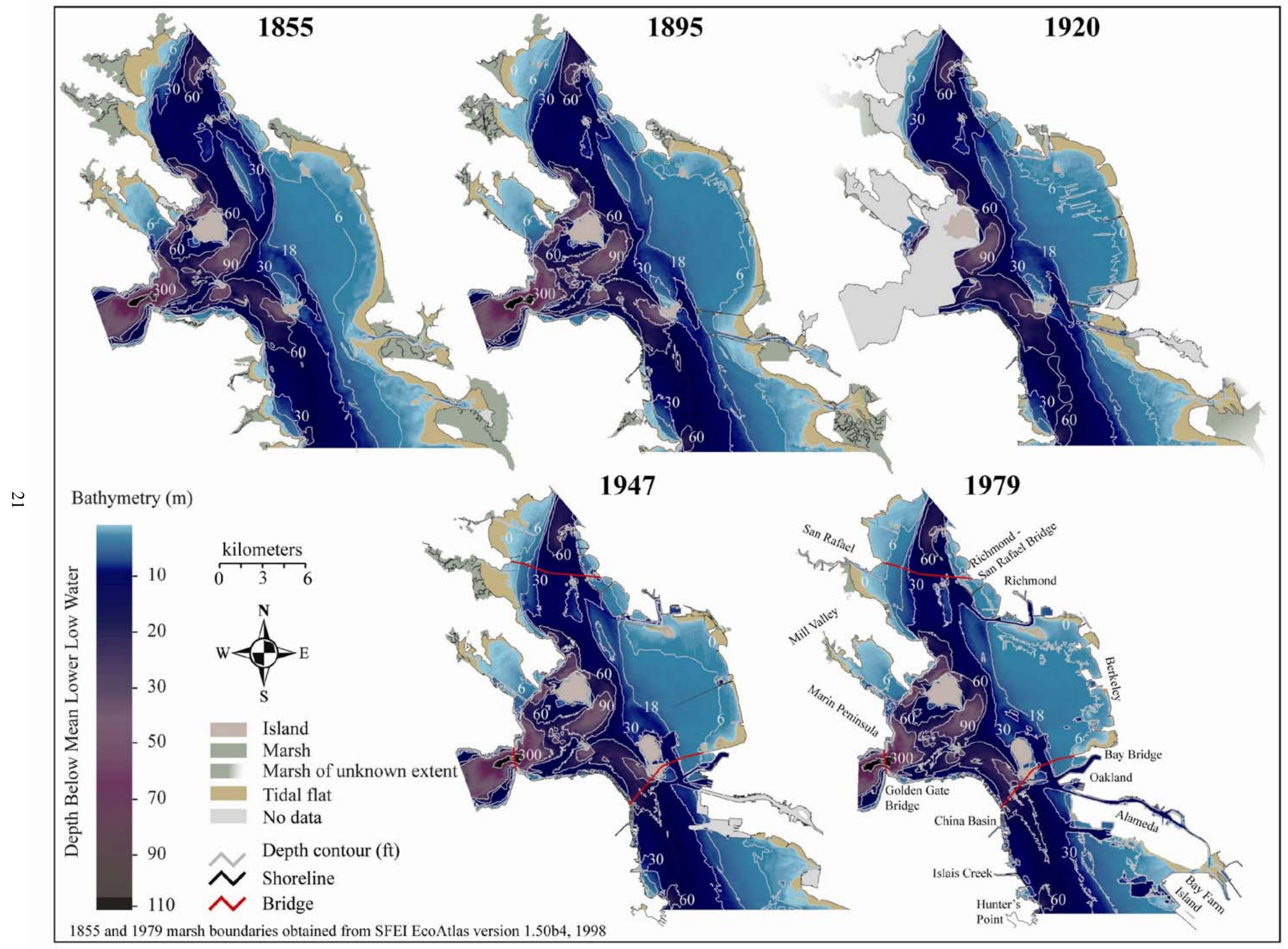

Figure 12. Preliminary bathymetry maps of Central San Francisco Bay from 1855 to 1979. 


\section{Bay Characteristics}

Examination of the bathymetric surfaces reveals interesting characteristics of Central San Francisco Bay's underwater topography. Figure 13 compares the geomorphology of the bay from the earliest survey period in 1855 and the latest in 1979 in a series of cross-sectional profiles. Profile A-A' is across the same span as the Richmond-San Rafael Bridge and shows the channel leading down from San Pablo Bay, the deposition on the west bank creating a narrower channel, with erosion, possibly dredging related, on the side. Profile $\mathrm{B}-\mathrm{B}$ ' shows the Tiburon to Point Richmond cross-section and the transition from two main channels to a main channel and smaller subchannel on the east side. The Alcatraz to Berkeley cross-section, C-C', shows only small changes, a slight deepening and widening of the small channel north of Treasure Island and west of the shallow shelf in the east bay. The Rincon Point to Alameda cross-section, D-D', starts off below MLLW because the piers on the San Francisco waterfront prevent shoreline access. The 1979 profile shows the channel deepening and shifting slightly to the east. This cross-section also shows the change in the Alameda shoreline as it was built out using bay fill. Profile E-E’, from Belvedere to Black Point in Fort Mason, shows deepening of the channel through Raccoon Strait, and sediment loss on Point Knox Shoal and the Presidio Shoal. The Golden Gate profile, $\mathrm{F}-\mathrm{F}$ ', indicates channel movement to the south, with an increase in depth. 


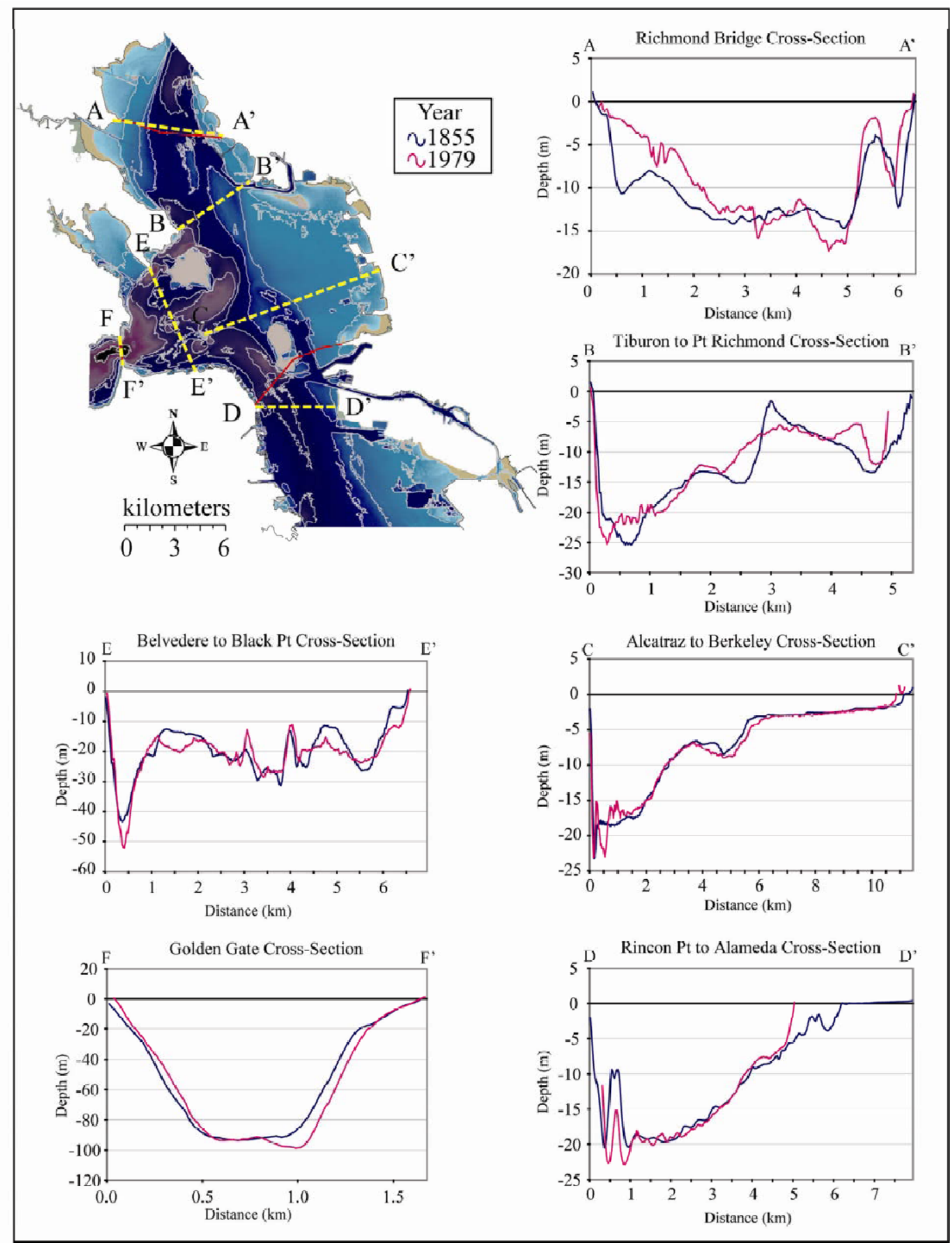

Figure 13. Preliminary series of cross section profiles showing the geomorphology of the bay floor in 1855 and 1979, depth relative to MLLW. 
Looking at the bathymetry from the 1979 survey, Central San Francisco Bay has the deepest areas of the entire estuary. The area west of the Golden Gate Bridge reaches a maximum depth of approximately 121 meters. The average depth for all of San Francisco Bay is 6 meters at MLLW (Conomos, 1979), but the average depth within our study area is approximately 11 meters at MLLW. Table 8 shows some general characteristics about Central San Francisco Bay.

Table 8. $\quad 1979$ Central San Francisco Bay characteristics, depth value relative to MLLW.

\begin{tabular}{||l|l|}
\hline \multicolumn{1}{|c|}{ Statistic } & \multicolumn{1}{|c|}{ Value } \\
\hline Average Depth & $11 \mathrm{~m}$ \\
\hline Surface Area & $304 \mathrm{~km}^{2}$ \\
\hline Tidal Flat Area & $12 \mathrm{~km}^{2}$ \\
\hline Navigable Area (deeper than $30 \mathrm{ft} / 9 \mathrm{~m}$ ) & $136 \mathrm{~km}^{2}$ \\
\hline Shallow Area (less than $6 \mathrm{ft} / 2 \mathrm{~m}$ deep) & $135 \mathrm{~km}^{2}$ \\
\hline
\end{tabular}

Shoreline and Area Change

Over the time span of this study, Central San Francisco Bay underwent major shoreline development that resulted in loss of area in the bay (fig. 14). Alterations to the shoreline and area of Central San Francisco Bay began between 1855 and 1895 with the utilization of bay fill to expand the San Francisco waterfront. After 1895, a rapid increase in population and development thrust San Francisco Bay into the major shipping and transportation hub that it became by the 1940s at the outset of World War II. Development resulted in a 4 percent loss of area in Central San Francisco Bay from 1855 to 1979. 


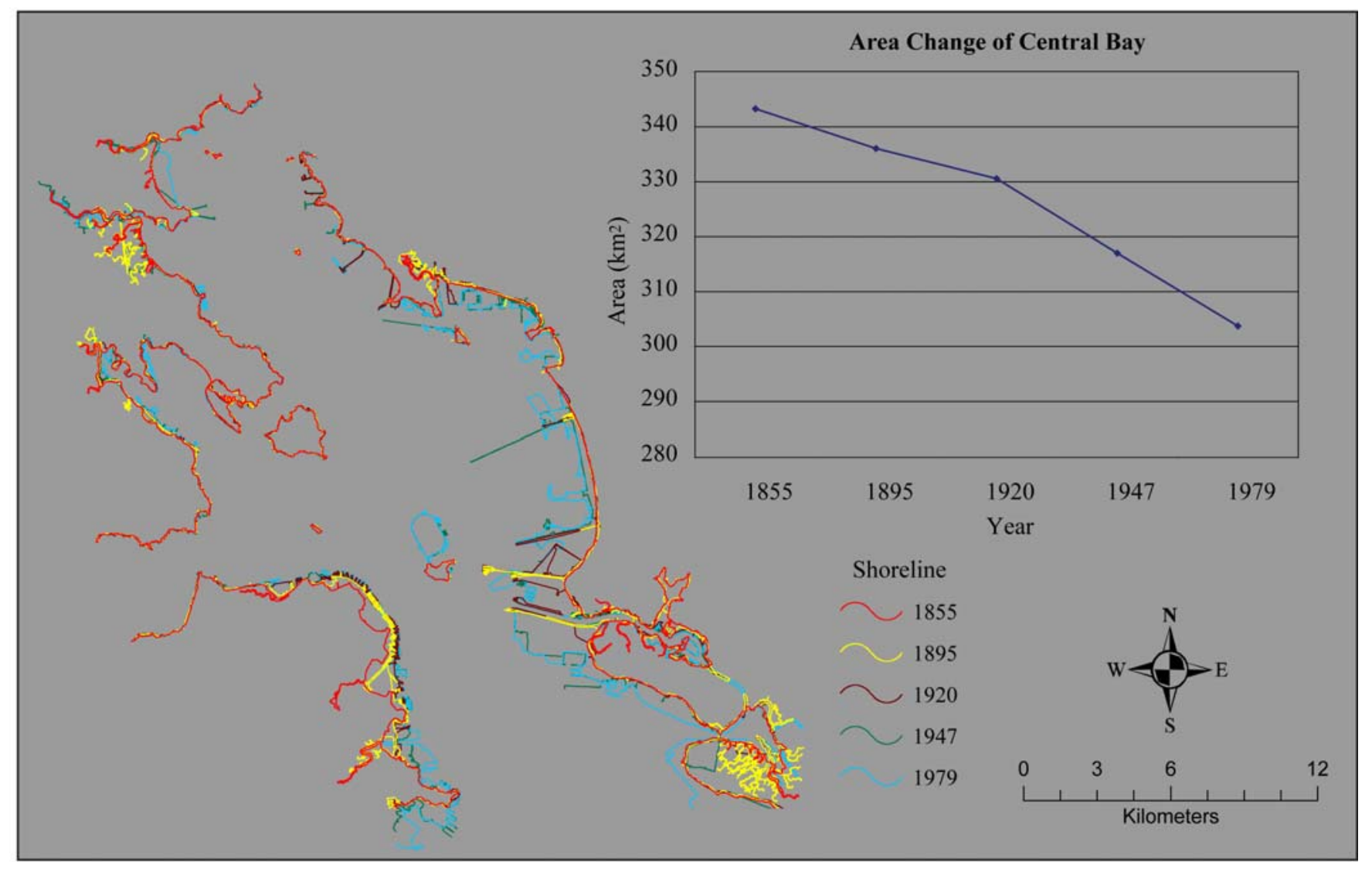

Figure 14. Map of shoreline change, including waterfront features, and graph showing area change in Central San Francisco Bay from 1855 to 1979.

\section{Area of Marsh}

From 1855 to 1979 approximately 93 percent of the marshlands in Central San Francisco Bay were lost (fig. 15). Since the time of the 1979 survey, numerous agencies have been working to restore marshlands throughout Central San Francisco Bay. Work has already been completed on many marsh restoration projects, with still more in the planning and implementation stages. New marshes have also been created on areas of bay fill. Information on wetland restoration in San Francisco Bay can be found at the Bay Area Wetland Tracker web site http://www.wetlandtracker.org (last accessed October 3, $\underline{2008)}$. 


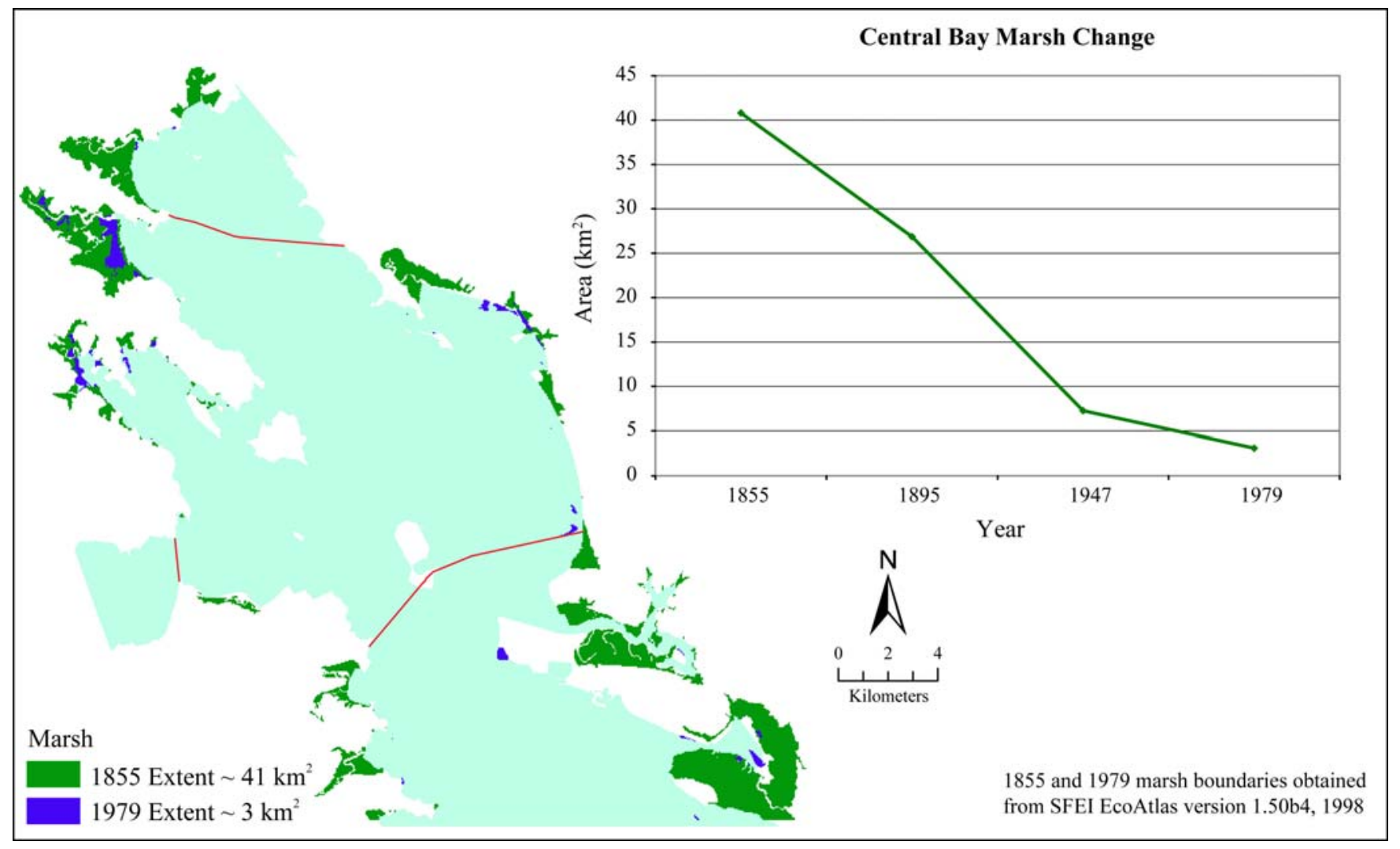

Figure 15. Map and graph showing marsh loss in Central San Francisco Bay from 1855 to 1979.

\section{Area of Intertidal Flat}

Central San Francisco Bay lost intertidal flat area between each survey period. Overall, the intertidal flats decreased from $40 \mathrm{~km}^{2}$ in 1855 to $12 \mathrm{~km}^{2}$ in 1979, a 69 percent decrease (fig. 16). Approximately $14 \mathrm{~km}^{2}$ was lost between the first two survey periods as the San Francisco waterfront was developed and changes occurred along the eastern shoreline (figs. 12, 14). Central San Francisco Bay lost approximately $4 \mathrm{~km}^{2}$ of intertidal flats from 1895 to 1947, with the majority of loss along the east bay shoreline (fig. 12). However, during this same period, intertidal flats grew along the western shoreline from San Pablo Bay to the top of the Tiburon Peninsula as the intertidal flats, almost returned to 1855 conditions. During the final time period from 1947 to 1979, Central San Francisco Bay lost almost $10 \mathrm{~km}^{2}$ of intertidal flats with the majority of the loss along the shoreline of San Rafael and the Tiburon Peninsula. 


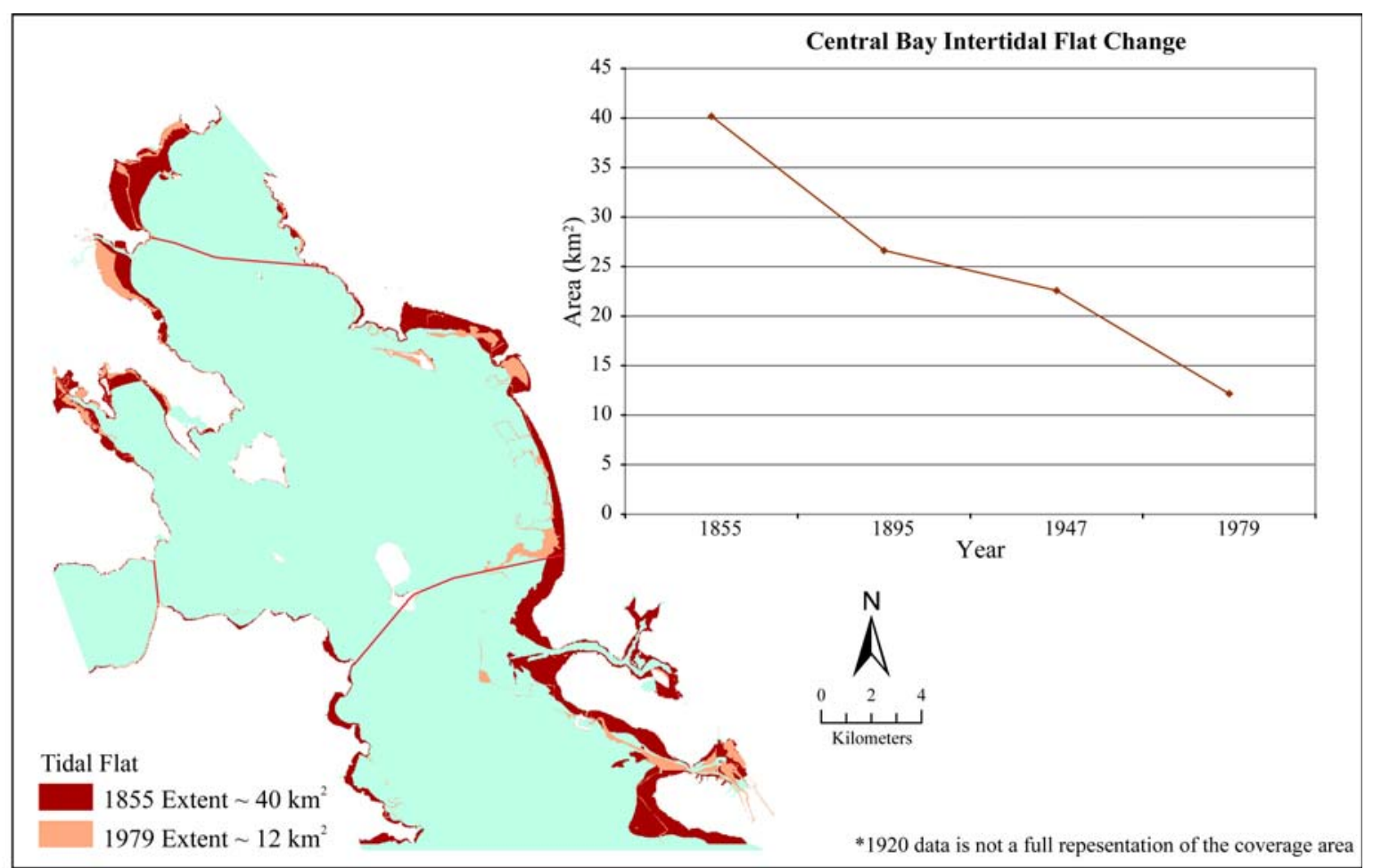

Figure 16. Map and graph showing change in intertidal flat area in Central San Francisco Bay from 1855 to 1979.

\section{Sediment Volume Changes in Central San Francisco Bay}

Changes in erosion and deposition in Central San Francisco Bay are shown in figure 17. Overall, the bay has experienced net deposition from 1855 to 1979 with a gain of approximately $42 \times 10^{6} \mathrm{~m}^{3}$ of sediment; however, deposition and erosion varied between survey periods and with location in the bay. The lack of a complete survey of the study area in the 1920 survey period makes it more challenging to understand changes in the sedimentation processes in Central San Francisco Bay over time. The change maps and calculations that include the 1920s time period are missing approximately 20 percent of the area included in the other change periods. From 1855 to 1895 the bay experienced an erosional period; approximately $75 \times 10^{6} \mathrm{~m}^{3}$ of sediment was lost from the system. From 1895 to 1920 and 1920 to 1947 there was a gain in sediment of approximately $77 \times 10^{6} \mathrm{~m}^{3}$ and $70 \times 10^{6} \mathrm{~m}^{3}$, respectively. Discounting the 1920 period because of its missing data, the gain in sediment is even greater from 1895 to 1947, $\sim 182 \times 10^{6} \mathrm{~m}^{3}$. The last time period, 1947 to 1979 , was one of loss, with approximately $52 \times 10^{6} \mathrm{~m}^{3}$ of sediment removed from the system.

Error in the calculated net gain or loss in sediment volume varies in space and time, with larger errors in steeply sloping regions where the grids are not as accurate and for earlier surveys (lower data density and greater uncertainty in vertical datum change between surveys). Although a complete error analysis is beyond the scope of this report, for sediment volume change calculations of large areas such as the ones presented here, the primary source of error is systematic error such as incorrect vertical datum correction (Jaffe and Foxgrover, 2006). For other subembayments of the San Francisco Estuary, systematic errors are less than 10 centimeters and typically on the order of one to several centimeters (Jaffe and Foxgrover, 2006; Jaffe and others, 2007). This equates to errors of approximately 3 to $30 \times 10^{6}$ $\mathrm{m}^{3}$ for Central San Francisco Bay. 


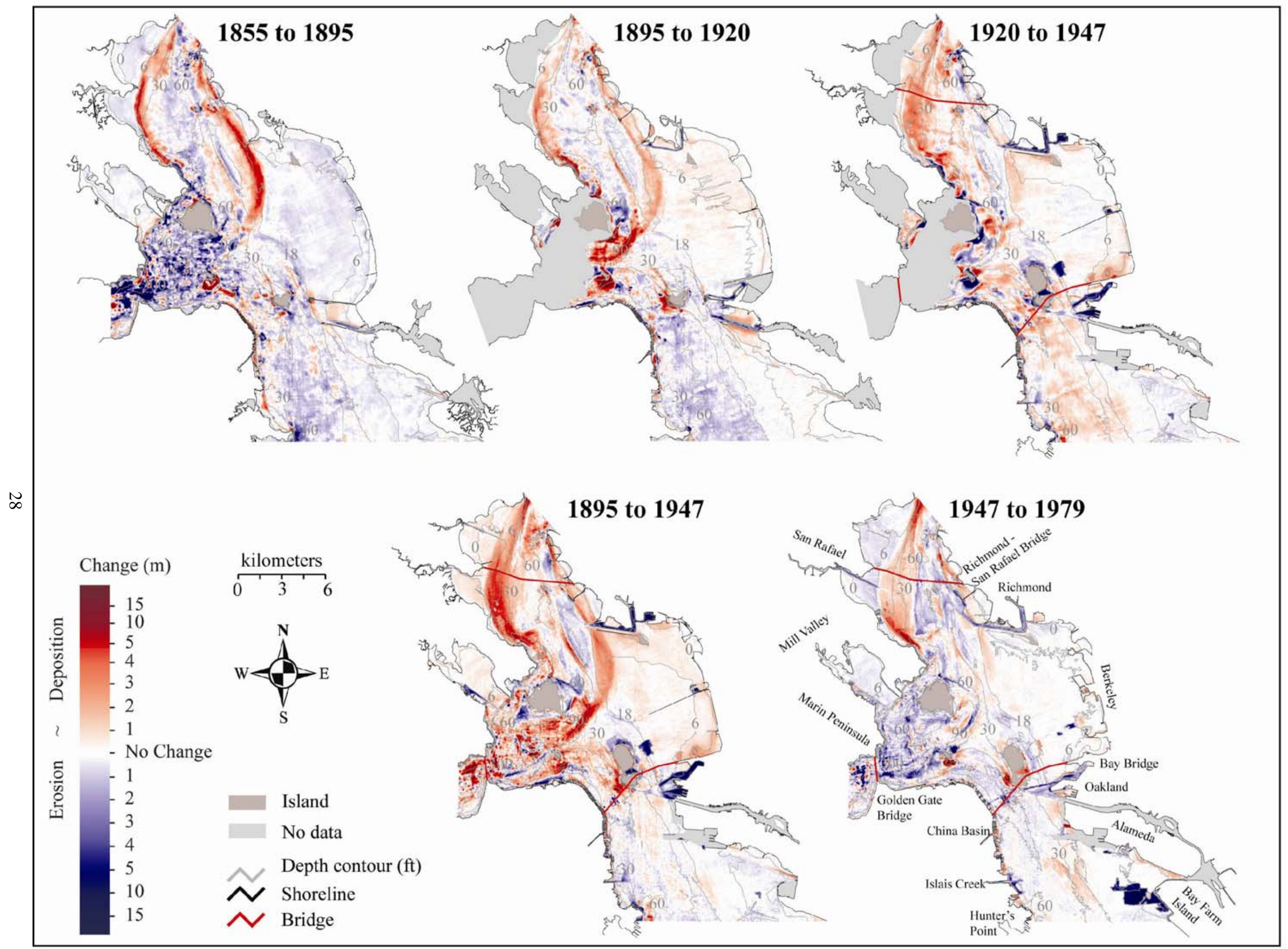

Figure 17. Preliminary maps showing sediment deposition and erosion in Central San Francisco Bay over time from 1855 to 1979. 


\section{Regional Net Sediment Volume Change}

In an effort to better grasp the sedimentation patterns in Central San Francisco Bay, the area was divided up into six regions based on geographical features and depth (fig. 18). Region 1 is the northernmost and encompasses the area south of San Pablo Bay to Point Bluff on the west and Point Richmond on the east. Region 2 covers the east bay region from Point Richmond in the north, following along the 18-foot contour to the Bay Bridge. Region 3 continues along the 18 foot contour from the Bay Bridge, covering the east side down to the limits of South San Francisco Bay. Region 4 contains the area west of the 18-foot contour and south of the Bay Bridge. Region 5 covers the area of the Golden Gate and is bounded by Regions 1, 2, 4, and 6. Region 6 is the area of Richardson Bay. The regions were modified for calculations both with and without the 1920s data.

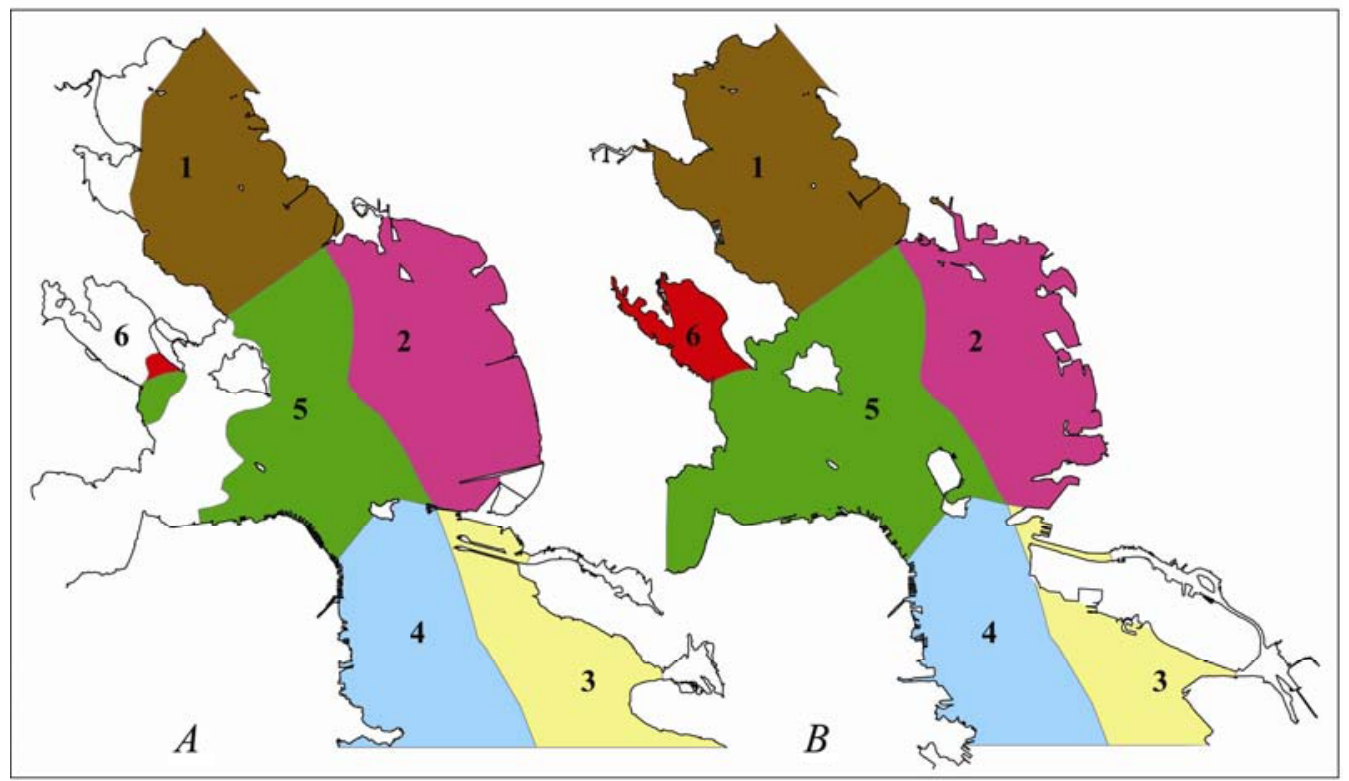

Figure 18. Map of Central San Francisco Bay showing the regions used for calculating regional net sediment volume change with $(A)$ and without $(B)$, the 1920 s data.

The volume of sediment gained or lost for each region over each change period is shown in figure 19. Only regions 2, 3, and 4 can be directly compared across all time periods because of areas of no data in the 1920s survey for regions 1, 5, and 6. Volume change was calculated from 1895 to 1947, bypassing the 1920s survey, for all regions to account for the lack of data in the 1920s. Evaluations of change over time for regions 1, 5, and 6 are best made from analyzing the 1855-1895, 1895-1947, and 1947-1979 time periods (thereby bypassing the incomplete 1920s survey). 


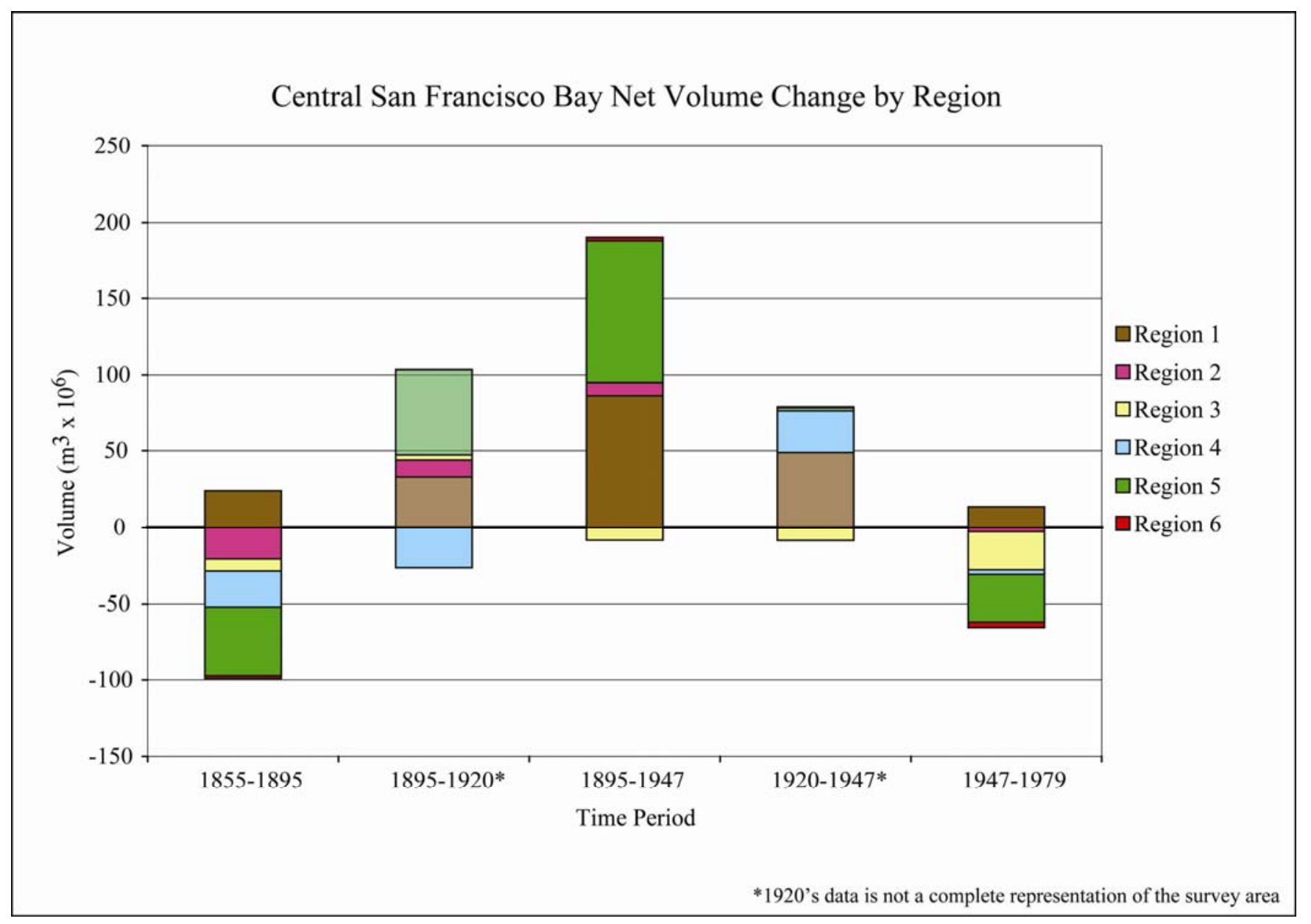

Figure 19. Graph showing Central San Francisco Bay preliminary net sediment volume change by region over time. Lighter colors for regions 1, 5, and 6 for 1895-1920 and 1920-1947 emphasize that volumes cannot be directly compared to other time periods because of smaller survey areas.

Region 1 is the only region that has held steady as a depositional area throughout the entire time period of this study. Region 1 gained the most sediment in the 1895 to 1947 era with a volume of $\sim 86 \times 10^{6} \mathrm{~m}^{3}$, which corresponds to an average bed level change of $2.47 \mathrm{~cm} / \mathrm{yr}$. The region gained the least in the 1947 to 1979 era, $\sim 14 \times 10^{6} \mathrm{~m}^{3}(0.65 \mathrm{~cm} / \mathrm{yr})$.

Region 2 alternated between being erosional and depositional. The region lost sediment from 1855 to $1895, \sim 21 \times 10^{6} \mathrm{~m}^{3}(-0.76 \mathrm{~cm} / \mathrm{yr})$, then gained back a bit more than half of what had been lost from 1895 to $1920, \sim 11 \times 10^{6} \mathrm{~m}^{3}(0.66 \mathrm{~cm} / \mathrm{yr})$. From 1920 to 1947 the region lost a minimal amount, $\sim 1 \times 10^{6} \mathrm{~m}^{3}(-0.04 \mathrm{~cm} / \mathrm{yr})$, and the loss continued in 1947 to 1979 , with a loss of approximately $\sim 3 \times 10^{6}$ $\mathrm{m}^{3}(-0.15 \mathrm{~cm} / \mathrm{yr})$.

Region 3 primarily lost sediment, with the greatest loss from 1947 to $1979, \sim 25 \times 10^{6} \mathrm{~m}^{3}(-3.14$ $\mathrm{cm} / \mathrm{yr}$ ). The only accretional period was from 1895 to 1920, when the region gained approximately $3 \times 10^{6} \mathrm{~m}^{3}(0.33 \mathrm{~cm} / \mathrm{yr})$.

Region 4 also appears to be mostly erosional, with one period of deposition from 1920 to 1947, $\sim 27 \times 10^{6} \mathrm{~m}^{3}(2.00 \mathrm{~cm} / \mathrm{yr})$ Similar amounts of sediment were lost from 1855 to 1895 and 1895 to 1920, 
approximately $23 \times 10^{6} \mathrm{~m}^{3}(-1.09 \mathrm{~cm} / \mathrm{yr})$ and $27 \times 10^{6} \mathrm{~m}^{3}(-2.02 \mathrm{~cm} / \mathrm{yr})$, respectively. A small amount of sediment was lost from 1947 to $1979, \sim 3 \times 10^{6} \mathrm{~m}^{3}(-0.18 \mathrm{~cm} / \mathrm{yr})$.

Region 5 alternated between being erosional and depositional. From 1855 to 1895 the region lost approximately $45 \times 10^{6} \mathrm{~m}^{3}(-1.26 \mathrm{~cm} / \mathrm{yr})$. Then from 1895 to 1947 the area gained approximately $93 \times 10^{6}$ $\mathrm{m}^{3}(2.05 \mathrm{~cm} / \mathrm{yr})$. From 1947 to 1979 the region was again erosional, with a loss of approximately $31 \times 10^{6} \mathrm{~m}^{3}(-1.11 \mathrm{~cm} / \mathrm{yr})$.

Region 6, the smallest region, also alternated between being erosional and depositional for the same time periods as region 5. From 1855 to 1895 there was a loss of approximately $2 \times 10^{6} \mathrm{~m}^{3}(-0.39$ $\mathrm{cm} / \mathrm{yr})$. From 1895 to 1947 there was a gain of approximately $2 \times 10^{6} \mathrm{~m}^{3}(0.40 \mathrm{~cm} / \mathrm{yr})$. In the last time period there was a larger loss of approximately $4 \times 10^{6} \mathrm{~m}^{3}(-1.07 \mathrm{~cm} / \mathrm{yr})$.

When interpreting calculations of deposition and erosion, it is important to consider the effects of unnatural alterations to the system. What may appear to be erosional may in fact be a sediment removal project. An area that appears to be deposition could be a dredge disposal area. The following section on "Anthropogenic Impacts on Net Sediment Volume Change" elaborates on some of the most obvious artificial changes made to the system. Appendix 1, "Differences in net volumes by region when accounting for sediment removed from the system," highlights the possible effects of sediment removal by showing the net change if the sediment had not been removed.

Net sedimentation rates were calculated in the six regions to determine how patterns of deposition and erosion vary spatially within the bay. Figure 20 shows the varying erosional and depositional trends for each region. These rates have been adjusted to discount the influence of artificial sediment removal. 


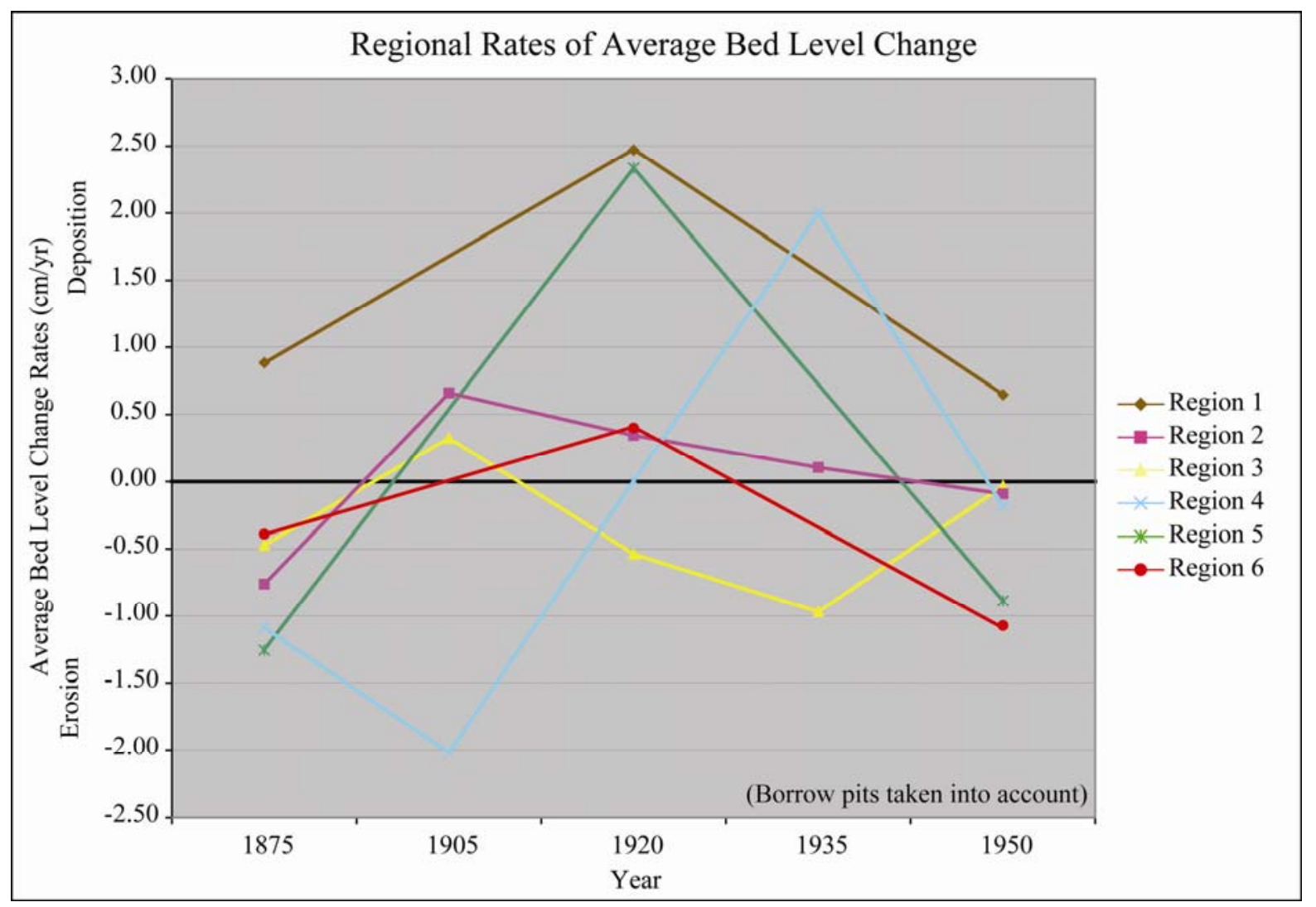

Figure 20. Graph showing preliminary regional rates of average bed level change over time (influences of borrow pits removed). Data for regions 1,5, and 6 have been excluded. The years displayed represent the midpoints between surveys (for example, 1920 is the midpoint between the 1895 and 1947 survey).

\section{Anthropogenic Impacts on Net Sediment Volume Change}

Understanding the patterns of sediment deposition and erosion in Central San Francisco Bay is not possible without accounting for the many anthropogenic alterations made to the system. The first federally recognized dredging project for navigational purposes was authorized by the Rivers and Harbors act of 1874, which allowed for dredging of the Oakland Harbor. Since that time there have been roughly 17 locations within Central San Francisco Bay that have been maintained by dredging under regulation by the Army Corps of Engineers (U.S. Army Corps of Engineers, 1975). According to Army Corps of Engineers records kept since the early 1930s, approximately $70 \times 10^{6} \mathrm{~m}^{3}$ of sediment was dredged during the period from 1931 to 1976 (see appendix 2). Before 1972 there were no regulations on where dredge disposal could occur, so disposal could happen anywhere. In the late 1800s a disposal site was started in a depression southwest of Alcatraz Island, and in the early 1900s another site was established southwest of Yerba Buena Island (U.S. Army Corps of Engineers, 1975). Disposal was also reported to occur on the east side of Angel Island. Not all dredge material was placed back in the system. In some instances the dredged material was immediately pumped onto a land disposal site, or used in land development projects (U.S. Army Corps of Engineers, 1975).

The removal of sediment and the creation of borrow pits strictly for use in development is first noted in 1935 when the Works Progress Administration approved the creation of Treasure Island for the Golden Gate International Exposition 1939-1940. This undertaking required $22.5 \times 10^{6} \mathrm{~m}^{3}$ of sediment dredged from within Central San Francisco Bay (Scheffauer, 1954) and an unknown amount from the 
Sacramento River Delta (Treasure Island Museum, 2003). Since that time other projects have required sediment from within Central San Francisco Bay. A large borrow area was established to the east of Bay Farm Island in the 1950s or 1960s, possibly for use in the expansion of the Oakland airport that occurred from 1960 to 1962.

Sand mining in San Francisco Bay started in the late 1800s and continues to date (Hanson Environmental Inc., 2004). A large portion of the fill used to create Treasure Island was sand mined from the sandy shoals in Central San Francisco Bay. Sand has been dredged regularly from Point Knox and Presidio Shoals, first to an authorized depth in the 1930s by the Army Corps of Engineers, then maintained at that depth by private interests as a borrow area (U.S. Army Corps of Engineers, 1975). Sand mining is now a regulated industry, with leases dictating the areas that can be mined and the volumes of sediment that can be removed each year. The first sand mine lease was awarded in 1952 by the State Lands Commission (Hanson Environmental Inc., 2004).

Figure 21 shows the most discernable bathymetric changes in Central San Francisco Bay attributable to human activities since the time of the earliest hydrographic surveys. In general, areas that are dredged for navigation simply moved sediment from one part of the system to another. The disposal areas just offshore of Alcatraz Island and Yerba Buena Island mark the location of the majority of dredge disposal. Sand mining and borrow pit dredging are always losses to the system. 


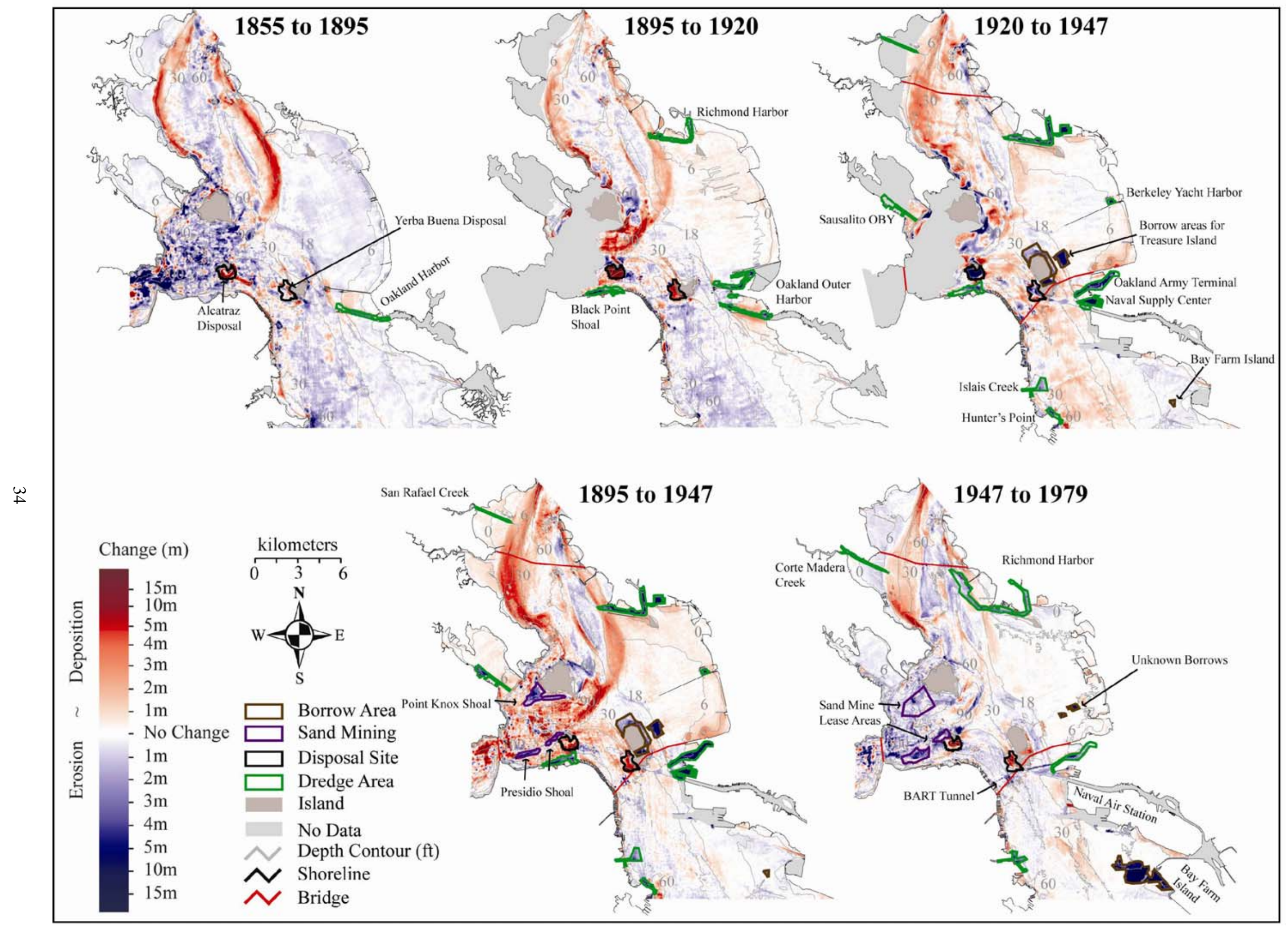

Figure 21. Maps showing some of the most discernable areas of man-made change over time, categorized by type. 
It is possible to estimate the volume of sediment affected by dredging and other activities using the change grids. However, it is difficult to separate the sediment volume change associated with anthropogenic activities from those associated with natural changes in deposition and erosion. Unless all the dredging or disposal occurred just before the collection of the survey (allowing no time for sediment to be redeposited at the site), the volumes calculated for these areas are minimum estimates.

According to volume calculations based on the change grids during the change period from 1895 to 1920 , approximately $2 \times 10^{6} \mathrm{~m}^{3}$ of sediment was dredged from Black Point and was probably removed from the system and disposed of outside of the Golden Gate at the San Francisco Bar (the ebb tidal delta). In the 1920 to 1947 period, approximately $8 \times 10^{6} \mathrm{~m}^{3}$ of sediment was removed from the borrow areas for the creation of Treasure Island. An additional $0.3 \times 10^{6} \mathrm{~m}^{3}$ of sediment was removed from the borrow pit just offshore of Bay Farm Island. During the period from 1895 to 1947, Central San Francisco Bay lost approximately $16 \times 10^{6} \mathrm{~m}^{3}$ of sediment from the system, and 98 percent of that is believed to have gone into the creation of Treasure Island (Scheffauer, 1954). During the last time period, 1947 to 1979, human activities removed the most sediment from the system. Of the approximately $32 \times 10^{6} \mathrm{~m}^{3}$ of sediment removed, 77 percent was from the large borrow area east of Bay Farm Island. In the sand mining lease areas, there was a net loss of $6 \times 10^{6} \mathrm{~m}^{3}$ from 1947 to 1979. A conservative estimate of sediment loss accounted for in these borrow pits, sand mining, and dredging with out of bay disposal, is shown in figure 22. The regional distribution of this loss is further explored in appendix 1 


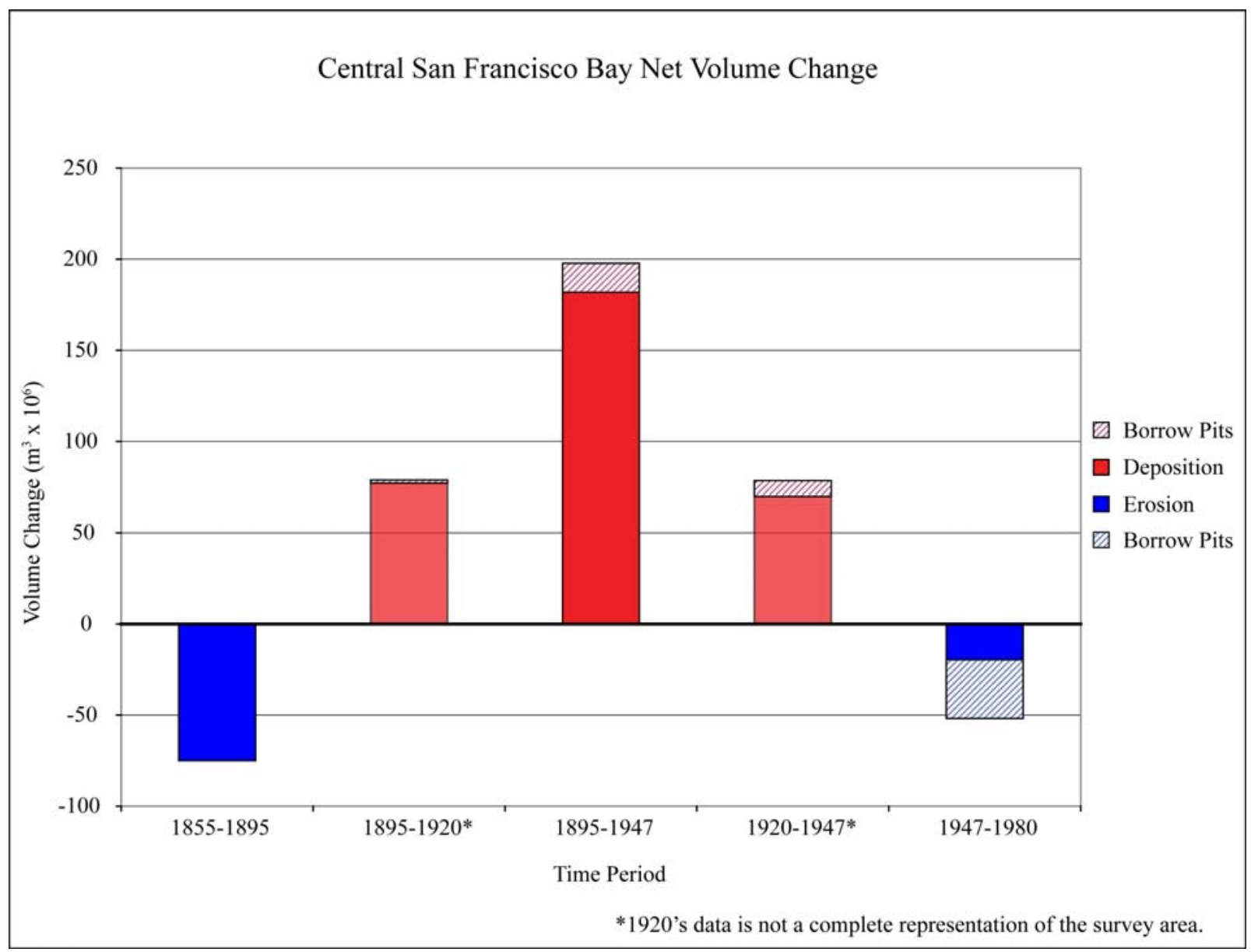

Figure 22. Graph of Central San Francisco Bay preliminary net sediment volume change calculations over time. The estimates for the minimum volume of sediment removed from borrow pits and sand mining are indicated by a hachured pattern.

\section{Future Work}

The completion of the bathymetric time series analyses for various sections of the San Francisco Bay Estuary now allows for the system to be viewed as a whole. A Bay-wide sediment budget can now be developed, and that information can be used to gain a better understanding of change within the entire San Francisco Estuary ecosystem over time. Sedimentation is a basic control on many processes that affect the ecosystem. The results of this study can be further analyzed to address: (1) transport of sediment to wetlands (affecting wetland erosion and health), (2) flow patterns and tidal exchange under altered bathymetry (affecting habitat distribution), and (3) bioavailability of trace metals and toxic sediments (deposition of clean sediments will bury contaminated sediments or erosion can expose contaminated sediments). 


\section{Acknowledgements}

This research was supported by the U.S. Geological Survey Priority Ecosystem Study of San Francisco Bay. This study was improved by the application of the techniques and approaches developed by Shawn Higgins on the historical bathymetric change of South San Francisco Bay (Higgins and others, 2005). This report was improved by reviews from Susan Cochran and Patrick Barnard.

\section{References Cited}

Bay Area Census web site, 2003 [http://www.bayareacensus.ca.gov/index.html , last accessed October 3, 2008].

Cappiella, K., Malzone, C., Smith, R., and Jaffe, B., 1999, Sedimentation and bathymetry changes in Suisun Bay; 1867-1900: U.S. Geological Survey Open-File Report 99-563 [http://geopubs.wr.usgs.gov/open-file/of99-563/, last accessed October 3, 2008].

Conomos, T.J., 1979, Properties and circulation of San Francisco Bay waters; in Conomos, T.J, San Francisco Bay; the urbanized estuary; San Francisco, Calif., American Association for the Advancement of Science, Pacific Division, p. 47-84

[http://www.estuaryarchive.org/archive/conomos_1979/8/,last accessed October 3, 2008].

Dedrick, K.G., 1983, Use of early hydrographic surveys in studies of California estuaries: Coastal Zone 1983, v 3, p. 2294-2316.

Department of Commerce Coast and Geodetic Survey, 1917, Descriptive Report Sheet No. 3928 and 3929.

Foxgrover, A.C., Higgins, S.A., Ingraca, M.K., Jaffe, B.E., and Smith, R.E., 2004, Deposition, erosion, and bathymetric change in South San Francisco Bay; 1858-1983: U.S. Geological Survey Open-File Report 04-1192 [http://pubs.usgs.gov/of/2004/1192/, last accessed October 3, 2008].

Hanson Environmental, Inc, 2004, Assessment and evaluation of the effects of sand mining on aquatic habitat and fishery populations of Central San Francisco Bay and the Sacramento-San Joaquin Estuary: Hanson Marine Operations, Inc, p. 2-1 - 2-4

[http://www.hansonenvironmentalinc.com/reports/Sand_Report_October_2004.pdf, last accessed October 3, 2008].

Higgins, S.A., Jaffe, B.E., and Smith, R.E., 2005. Bathychronology; reconstructing historical sedimentation from bathymetric data in GIS: U.S. Geological Survey Open-File Report 05-1273 [http://pubs.usgs.gov/of/2005/1273/, last accessed October 3, 2008].

Jaffe, B.E., and Foxgrover, A.C., 2006, Sediment deposition and erosion in South San Francisco Bay, California from 1956 to 2005: U.S. Geological Survey Open-File Report 2006-1287, 24 p [http://pubs.usgs.gov/of/2006/1287, last accessed October 3, 2008].].

Jaffe. B.E., Smith, R.E., and Torresan, L., 1998, Sedimentation and bathymetric change in San Pablo Bay; 1856-1983: U.S. Geological Survey Open-File Report 98-759 [http://geopubs.wr.usgs.gov/openfile/of98-759 , last accessed October 3, 2008] .

Jaffe. B.E., Smith, R.E., and Foxgrover, A.C., 2007, Anthropogenic influence on sedimentation and intertidal mudflat change in San Pablo Bay, California; 1856-1983: Estuarine Coastal and Shelf Science, 77, p. 175-187.

Mitchell, H.C., 1936, First and second order triangulation in California (1927 Datum): U.S. Coast and Geodetic Survey, Washington, D.C., Special Publication No. 202. 
National Geophysical Data Center, 1996, Geophysical data system for hydrographic survey data, version 3.3, CD-ROM set.

Rink, M.D., 2003, San Francisco Bay shoreline digitization project: Charleston, South Carolina, National Oceanic and Atmospheric Administration.

San Francisco Estuary Institute, 1998, EcoAtlas: version 1.50b4, CD-ROM.

Scheffauer, F.C., 1954, The hopper dredge, its history, development, and operation: U.S. Army Corps of Engineers, p. 366-369.

Treasure Island Museum Web site, 2003 [http://www.treasureislandmuseum.org, last accessed October 3, 2008].

United States Geological Survey San Francisco Bay Bathymetry Web site [http://sfbay.wr.usgs.gov/sediment/sfbay/index.html, last accessed October 3, 2008].].

U.S. Army Corps of Engineers, 1975, Final composite environmental statement; maintenance dredging, existing navigation projects, San Francisco Bay Region, California: U.S. Army Corps of Engineers, San Francisco District, vol. 1, p. I-3 - 1-70 [http://www.spn.usace.army.mil/ltms/ces_1975.pdf, last accessed October 3, 2008].].

U.S. Environmental Protection Agency, 2008, San Francisco Estuary Project Web site, 2008 [http://www.epa.gov/owow/estuaries/programs/sfe.htm\#overview , last accessed October 3, 2008]. 


\section{Appendix 1: Differences in Net Volumes by Region when Accounting for Sediment Removed from the System}

\begin{tabular}{|c|l|l|l||}
\hline & \multicolumn{1}{|c|}{ 1855-1895 } & \multicolumn{1}{c|}{ 1895-1947 } & \multicolumn{1}{c||}{$1947-1979$} \\
\hline & $\begin{array}{c}\text { Net Volume } \\
\text { (Volume without removal) } \mathrm{m}^{3} \times 10^{6}\end{array}$ & $\begin{array}{c}\text { Net Volume } \\
\text { (Volume without removal) } \mathrm{m}^{3} \times 10^{6}\end{array}$ & $\begin{array}{c}\text { Net Volume } \\
\text { (Volume without removal) } \mathrm{m}^{3} \times 10^{6}\end{array}$ \\
\hline Region 1 & 24.13 & 86.30 & 13.62 \\
\hline Region 2 & -20.76 & $8.61(10.97)$ & $-2.82(-1.71)$ \\
\hline Region 3 & -7.93 & $-8.55(-8.27)$ & $-25.14(-0.28)$ \\
\hline Region 4 & -23.31 & 0.11 & -2.91 \\
\hline Region 5 & -45.33 & $93.09(106.32)$ & $-31.03(-24.85)$ \\
\hline Region 6 & -1.79 & 2.28 & -3.52 \\
\hline Total & -74.99 & $181.85(197.71)$ & $-51.80(-19.65)$ \\
\hline
\end{tabular}

\begin{tabular}{|c|c|c|}
\hline & $1895-1920^{1}$ & $1920-1947^{1}$ \\
\hline & $\begin{array}{c}\text { Net Volume } \\
\text { (Volume without removal) } \mathrm{m}^{3} \times 10^{6}\end{array}$ & $\begin{array}{c}\text { Net Volume } \\
\text { (Volume without removal) } \mathrm{m}^{3} \times 10^{6}\end{array}$ \\
\hline Region 1 & 33.10 & 48.74 \\
\hline Region 2 & 10.74 & $-0.65(1.72)$ \\
\hline Region 3 & 3.31 & $-7.98(-7.66)$ \\
\hline Region 4 & -26.56 & 27.22 \\
\hline Region 5 & $56.41(58.10)$ & $2.01(7.75)$ \\
\hline Region 6 & 0.06 & 0.70 \\
\hline Total & $77.06(78.76)$ & $70.04(78.47)$ \\
\hline
\end{tabular}

${ }^{1}$ Change periods including the 1920s survey do not encompass all of Central San Francisco Bay. Therefore regions 1, 5, and 6 in this survey are not a complete reflection of sediment trends. 


\section{Appendix 2: Amounts of Dredged Material as Recorded by the U.S. Army Corp of Engineers (1975).}

\begin{tabular}{|c|c|c|c|c|}
\hline Dredge Location & $\begin{array}{c}\text { Disposal } \\
\text { in bay } \\
(\mathrm{mcm})^{1}\end{array}$ & $\begin{array}{l}\text { Disposal } \\
\text { outside } \\
\text { bay } \\
(\mathrm{mcm})^{1}\end{array}$ & Dates & Disposal Location \\
\hline \multirow[t]{2}{*}{ Presidio Shoal } & & ? & 1931 & San Francisco Bar \\
\hline & & $>0.04$ & 1963 & San Francisco Bar \\
\hline Point Knox Shoal & & ? & 1933 & San Francisco Bar \\
\hline Alcatraz Shoal & & $?$ & 1932 & San Francisco Bar \\
\hline Black Point Shoal & & $?$ & 1937 & San Francisco Bar \\
\hline Islais Creek Entrance & 0.99 & & $1950-1973$ & Alcatraz \\
\hline \multirow[t]{2}{*}{ San Rafael Creek } & & 1.00 & $1931-1951$ & Land \\
\hline & & 0.99 & $1954-1970$ & Land \\
\hline \multirow[t]{3}{*}{ Richmond Harbor Project } & 4.54 & 3.55 & 1932-1951 & Bay and land \\
\hline & 8.31 & 1.10 & $1951-1971$ & East of Angel Island, and land \\
\hline & 1.73 & & $1972-1976$ & Alcatraz \\
\hline \multirow[t]{4}{*}{ Oakland Harbor* } & ? & $?$ & 1874 & Unknown \\
\hline & 5.47 & 2.34 & $1931-1947$ & Yerba Buena Island, land \\
\hline & 13.18 & & $1948-1969$ & Yerba Buena Island \\
\hline & 2.97 & 0.06 & $1971-1976$ & Alcatraz \\
\hline \multirow[t]{2}{*}{ Sausalito Operations Base Yard } & 0.24 & 0.00 & $1951-1961$ & $\begin{array}{l}\text { Yellow Bluff light station, } 100 \text { feet of } \\
\text { water }\end{array}$ \\
\hline & 0.12 & 0.00 & 1967-1968 & Alcatraz \\
\hline \multirow[t]{3}{*}{ Alameda Naval Air Station (NAS) } & 8.10 & 0.62 & $1959-1974$ & $\begin{array}{l}\text { Often near the entrance to the NAS, } \\
\text { unknown }\end{array}$ \\
\hline & & 0.68 & 1975 & San Francisco Bar Site \\
\hline & ? & & $>1975$ & Alcatraz \\
\hline MOTBA North & 0.06 & 0.00 & 1958, 1967 & Southwest of Yerba Buena Island \\
\hline \multirow[t]{4}{*}{ Naval Supply Center-Oakland (NSC) } & & 3.15 & 1940 & Fill for construction of NSC \\
\hline & & 2.09 & $1942-1943$ & Landfill at Alameda Naval Air Station \\
\hline & 0.59 & & 1943 & Unknown \\
\hline & 3.46 & & $1946-1970$ & Southwest of Yerba Buena Island \\
\hline MOTBA East & 0.21 & ? & 1967-1970 & $\begin{array}{l}\text { Disposal at Alcatraz or } 100 \text {-fathom } \\
\text { disposal site }\end{array}$ \\
\hline \multirow[t]{2}{*}{ Point Molate } & 3.08 & & $1943-1958$ & Possibly at Alcatraz \\
\hline & 0.96 & & $1965-1975$ & Possibly at Alcatraz \\
\hline
\end{tabular}




\begin{tabular}{|l|l|l|l|l|}
\hline \multicolumn{1}{|c|}{ Dredge Location } & $\begin{array}{c}\text { Disposal } \\
\text { in bay } \\
(\mathrm{mcm})^{1}\end{array}$ & $\begin{array}{c}\text { Disposal } \\
\text { outside } \\
\text { bay } \\
(\mathrm{mcm})^{1}\end{array}$ & \multicolumn{1}{|c|}{ Dates } & \multicolumn{1}{c|}{ Disposal Location } \\
\hline Government Island & & 0.01 & 1937,1947 & $\begin{array}{l}\text { Material placed south of the channel, } \\
\text { outside of the study area. }\end{array}$ \\
\hline & 0.02 & & $1950-1967$ & Southwest of Yerba Buena Island \\
\hline Horseshoe Cove, Fort Baker & 0.00 & & 1944 & Off coast of Yellow Bluff \\
\hline & 0.01 & & 1971 & Alcatraz \\
\hline
\end{tabular}

${ }^{1}$ Million cubic meters.

*Approximately half of the dredged material listed for Oakland Harbor is from the inner harbor, which is not included in the bathymetric change maps. 